\title{
Identification of Paleo-Volcanic Rocks on Seismic Data
}

\author{
Sabine Klarner and Olaf Klarner \\ PGS Reservoir E Klarenco \\ Germany
}

\section{Introduction}

While exploring for hydrocarbons in rift related basins, volcanics, volcaniclastic deposits or their erosional products are common lithologies. The presence of rock types derived from volcanism and/or affected by post-volcanic re-deposition may lead to complex lithologies with complex diagenetic overprints at the reservoir level. Partial or complete reservoir substitution, alteration by circulating hot fluids and addition of mineral components have led to a number of unsuccessful wells, both in exploration and field development projects. Furthermore, volcanic rocks may form lateral seals or migration barriers, providing both positive and negative impact on the petroleum system. Non-permeable volcanic layers can seal the top of the reservoir, preventing it from breaching, or they can build a migration barrier for the fluid on its way from the source rock into the trap. In most cases, highly varied lithologies with wide ranges of inherent rock properties occur. It is therefore essential to understand the distribution of volcanics in the vicinity of the reservoir.

Published examples of volcanic reflectors identifiable from seismic data are still very sparse, and there is no systematic compilation of information and knowledge available. Free air gravity maps, as well as other potential field methods, may show anomalies caused by volcanic and sub volcanic bodies if they are really massive geobodies. Unfortunately, the majority of volcanic features are rather thin (some tens of meters thick). At a reservoir depth of more than $3 \mathrm{~km}$ the resolution of standard potential field data is not good enough to delineate the individual units.

A close cooperation of specialists from different disciplines is required in order to resolve specific problems related to seismic interpretation and reservoir prediction within such a complex environment. Sedimentology and fieldwork studies of recent analogues provide the basis for recognition of the depositional environment used for seismic interpretation. Special seismic processing must be utilized to calculate attributes from prestack data, showing amplitude variations with increasing offset from the energy source (commonly referred to as AVO analysis). These data are interpreted using results from rock physics analysis - elastic parameters of different lithology types and seismic forward modeling. The AVO analysis is used to support the lithology identification from seismic geometries. The input for the rock physics is delivered by the petrophysicist - log derived properties and interpretations. Petrography is used for provenance analysis, as well as analysis of diagenesis and fabric. In many cases, this turns out to be the key to understanding the anomalous AVO behavior of sandstones. Finally, sequence stratigraphy relates the different levels of sandstones to periods with and without volcanic activity. 
Our experience from working in different basins around the world has shown that there are certain distinct features that can assist in the identification of volcanics and volcanic related lithologies from seismic data. These features can be divided in two main groups: (1) geometry, specifically in comparison with observed morphology of recent volcanics and (2) amplitude expression, particularly the AVO behavior. Modern seismic interpretation technologies, such as 3D imaging, spectral decomposition, analysis of elastic rock properties and $\mathrm{AVO}$ analysis in combination with sound geological understanding of recent volcanism reveal completely new insights into the geological past.

In the current chapter both geometry and amplitude behavior of volcanics, as seen in seismic and well data will be discussed using a number of case studies from several hydrocarbon bearing basins around the world. The chapter summarizes previously presented ideas with a special emphasis on the multidisciplinary approach required to succeed with seismic interpretation.

\section{Seismic geometries of paleo-volcanics}

\subsection{Overview}

In this section, we will discuss typical shapes and images seen on seismic data resembling geometries observed in recent areas with volcanic activity. The best images stem from seismic data offshore Brazil, from the Upper Cretaceous reservoir section in the Santos Basin. The Santos Basin, offshore Brazil, is an ideal place to study the seismic signature of volcanic rocks embedded in a clastic section. The volcanism of the Santos Basin is a product of the late phase of rifting, which led to the opening of the Atlantic. The Santos basin itself is underlain by stretched continental crust with deep-reaching faults supporting the ascent of mafic melts from the upper mantle (Mohriak et al, 2002).
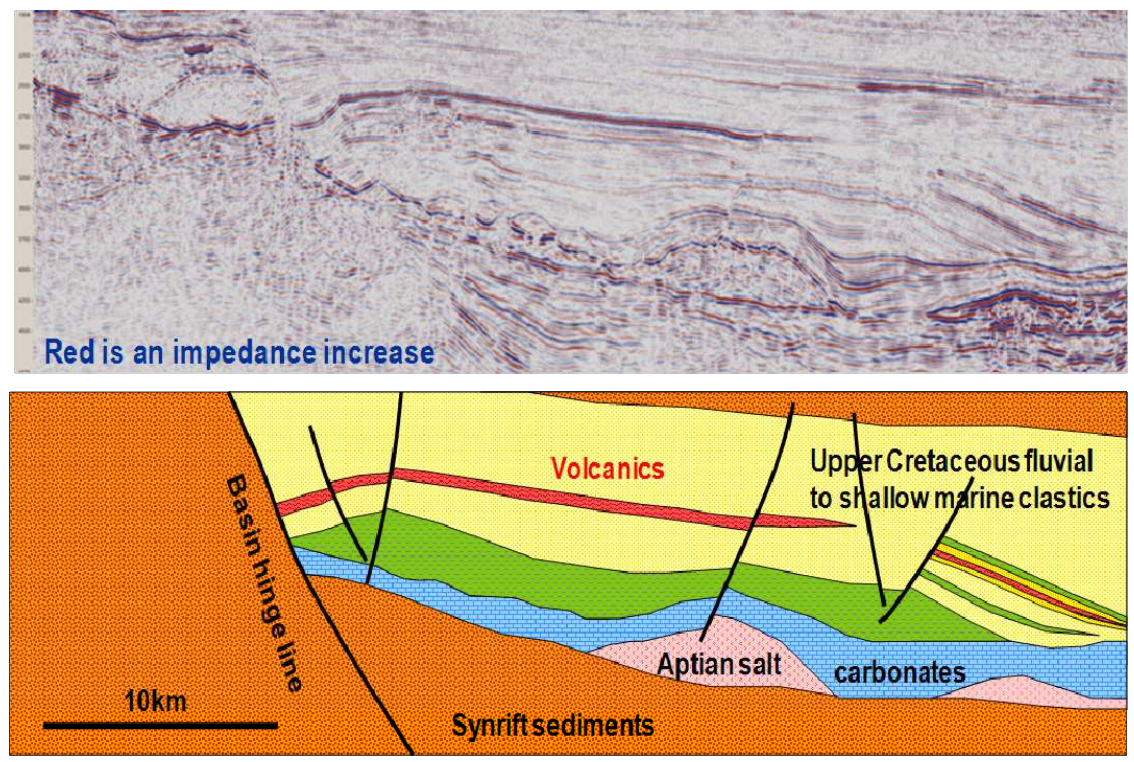

Fig. 1. Schematic interpretation of a NW-SE striking seismic section from the Santos Basin, crossing the basin hinge line 
The basalts encountered in exploration wells are located along the basin hinge line (Fig. 1) that controlled basin geometry and sedimentation during the Upper Cretaceous (e. g. the Aptian salt distribution). This gave rise to the assumption that this fault trend was very active and formed an ideal conduit for the magma. Interestingly, the occurrences of magma not only follow the main fault, but also smaller fractures associated with it. Within the area of interest, at least four stages of Upper Cretaceous volcanic activity have been recognized. The age of the volcanics ranges between 80 and 65 Mio years and they occur at a depth range of $3200-4600 \mathrm{~m}$.

\subsection{Volcanic geometries}

The geometries of the mapped individual volcanic bodies display a wide range of features, well known from recent surface volcanoes. Within the area of investigation, four different types of volcanic features have been mapped:

1. Massive basalt flows, indicative of sub aqueous cones and small plateaus with a thickness of several tens to hundreds of meters, covering an area of up to $400 \mathrm{~km}^{2}$.

Most of the sub aqueous volcanoes consist, to a large extent, of pillow lava flows. Lava tubes occur at low to medium eruption rates presumably from central chimneys and short conveyor cracks. The size of the lava pipes decreases with increasing height of the volcano. Pillows tend to solidify completely, later compaction will not substantially change their internal structure and the amplitude response will be unambiguous. As a pillow forms, a new eruption phase will cover the predecessor over the top and then flow outward. This process builds steep sided mounds in contrast to sheet flows that occur at higher eruption rates and lead to flatter shield volcano features. It is assumed that an alternation of sheet flows and pillow lava commonly occurs with a ratio of 30 to $70 \%$ (Schminke, 2000). Extension of these sheets can reach hundreds of square kilometers with considerable thicknesses. Core data and Formation Micro Images (FMI) data from an exploration well in the target area show pillow lava sections, but also layers of hyaloclastic rocks within basalt lava flows. These were deposited as debris from the cooling pillow lava flow. Due to their fragility and re-deposition processes, only remnants may have been preserved.

The geomorphology of volcanic lava or pyroclastic flows can in many cases display similar features to siliciclastic facies like turbidities or fluvial delta deposits (Fig. 2). This can lead to serious pitfalls in hydrocarbon exploration.

\section{Massive aerial basalt flows with single lava flow geometries}

Depending upon viscosity, flow velocity, and eruption rate, for monogenetic basalt flows a number of different surface features can be observed. In general the surface is glassy, and tends to peel off due to the brittleness of the rock. If viscosity and shear strain rise, the more liquid Pahoehoe lava will convert into the blocky Aa lava (Schminke, 2000). During the cooling phase, a regular fracture system is developed. The more rapid cooling of the surface of a lava flow results in the lower third of the flow developing regular pillars which are overlain by a layer with vaulted and less regular offsets. The upper layer is more brittle than the lower and can be sheared off during later tectonic movements. This is important for hydrocarbon exploration. If fractures remain open, hydrocarbons can escape through these pathways leaving the potential target empty. In thick lava flow deposits, the pillar part can be subdivided into a lower part with broad pillars, a middle "Entablature" zone with thin pillars, and the unstructured upper part. Due to the low viscosity of the Pahoehoe Lava, we 
can observe relatively thin bedded flow units, which can be stacked on top of each other (Fig. 3,4), jointly cooled down leading to complex flow units (Schminke, 2000). These complex flow units develop different internal facies distribution with different properties such as brittleness and shear strain (Nelson 2009).

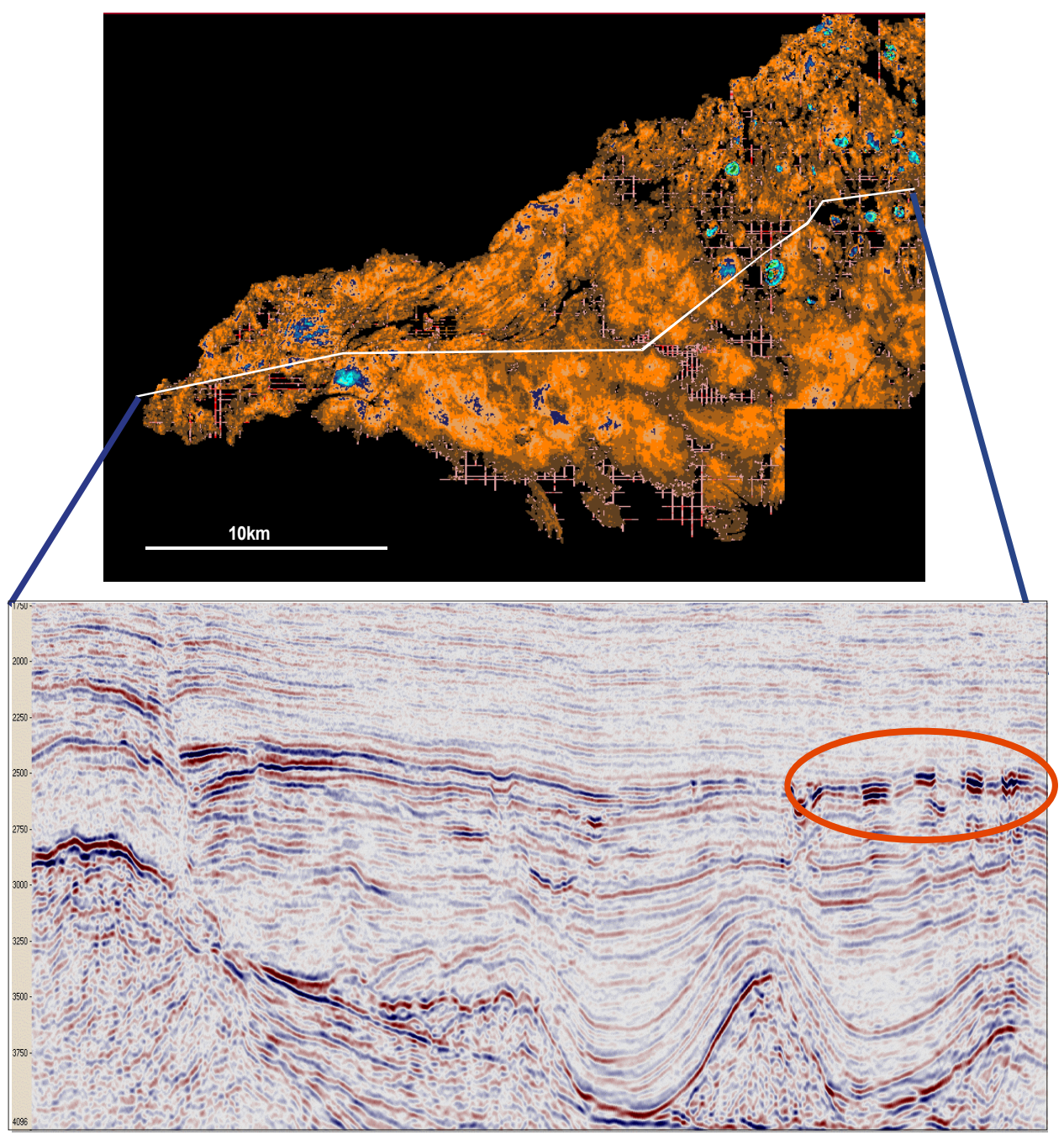

Fig. 2. Amplitude map of a sharply defined massive mainly sub aerial lava flow consisting of several separate units and exhibiting numerous vents (circular features with strong amplitudes) 


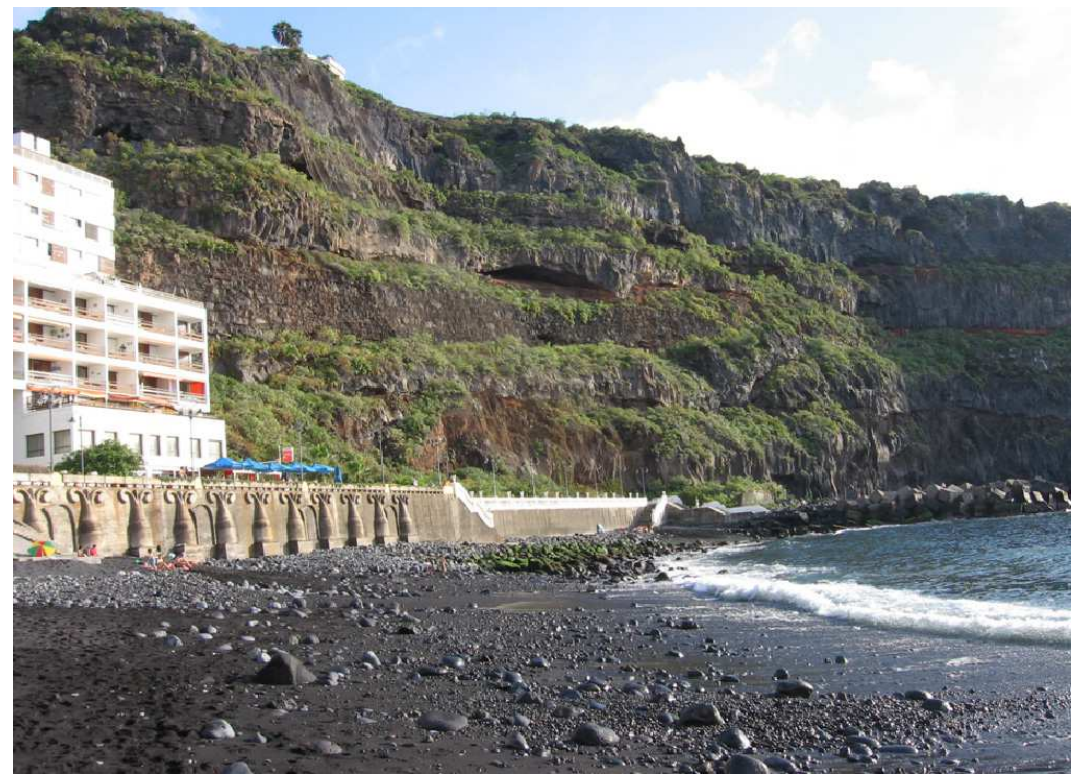

Fig. 3. Outcrop example of multiple stacked lava flows, North East coast Tenerife, 2006, Klarner

The outcrop sample from Tenerife serves as an analogue for the observed stacked lava flows in deep water exploration wells in the Santos Basin, Brazil (Fig. 4).

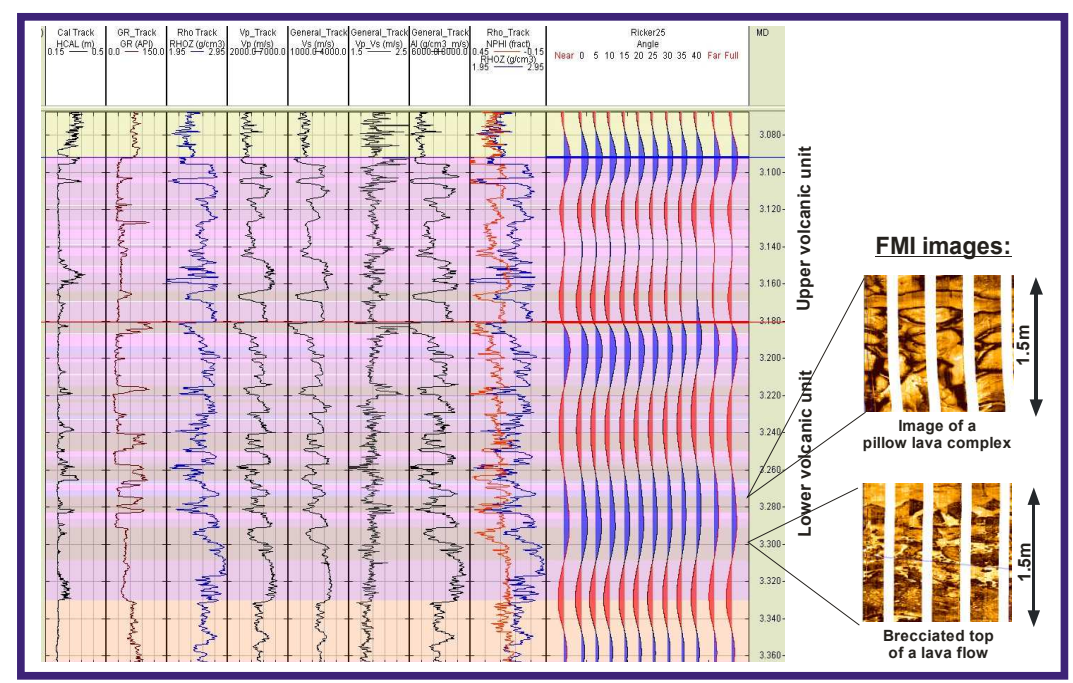

Fig. 4. Upper Cretaceous multiple stacked lava flows, drilled in the Santos basin. The sawtooth log pattern reflects the individual flow units, each beginning with massive basalt and ending with a brecciated (weathered) top. The lower unit contains pillow lavas, indicating subaqueous deposition 
In addition, we need to account for the limited resolution capability of seismic data. Individual effusive events have thicknesses from a single meter up to 10 or maximum 15 meters. We see this in the outcrop (Fig.3), but also within the well log data (Fig.4). The seismic resolution depends on the velocity of the seismic waves and the frequency of the signal, and for a p-wave velocity of $3500 \mathrm{~m} / \mathrm{s}$ and a lead frequency of $35 \mathrm{~Hz}$ we can assume a vertical resolution power of about $25 \mathrm{~m}$ (equals a quarter of the wavelength), for $5000 \mathrm{~m} / \mathrm{s}$ and $25 \mathrm{~Hz}$ we can see cycles of about $50 \mathrm{~m}$ thickness. This means, that in reality many effusive events are always compiled into one phase of the seismic data - as seen on the right column of Fig. 4. The resolution can be slightly enhanced by procedures like spectral decomposition or inversion, revealing details of the internal structure, but there is still a significant resolution limit inherent in the data.

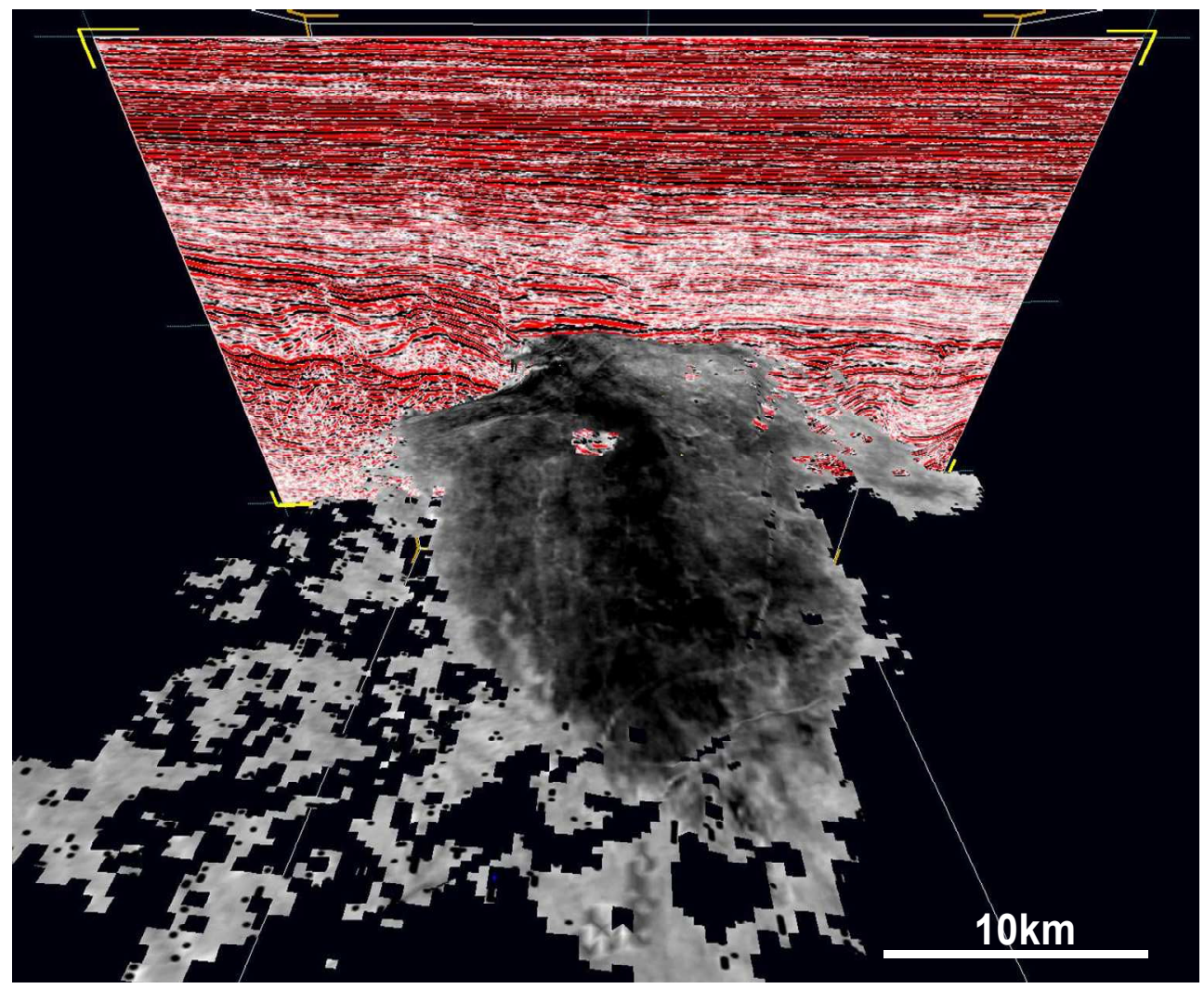

Fig. 5. 3D seismic image of a small shield volcano, covered by over $3000 \mathrm{~m}$ sediments (Santos Basin)

Typical features of low viscosity basalt flows are pipe vesicles and vesicle cylinders. We believe that these surface features do not play a role after compaction and subsidence of several thousand meters (Fig. 5). The analogs known from surface are important for a good understanding of the subsurface features, but a one to one comparison might not be adequate. Hence, our model of paleo-volcanoes requires some adjustment in terms of 
subsidence, lithostatic pressure and the respective diagenetic alterations. Under surface or subaqueous conditions, the lateral extent of low viscous lava flows is normally short due to the increasing viscosity caused by decreasing temperature. However, the reach can be substantial in the case of transportation through lava pipes. Hence, volcanic rock features can occur miles away from identified sources like a volcano or main fault system.

In many areas with predominantly mafic volcanism, the Aa-lava type is prevalent (Schminke, 2000). These lava flows are characterized by cindery, sharp-edged boulders, which can be strongly welded. Such flow units have a lower part with boulders and scoria, whereas the upper part consists of successive flow units. Aa- flow units do not have a large aerial extent and will be found closer to the volcanic source (Fig. 6).

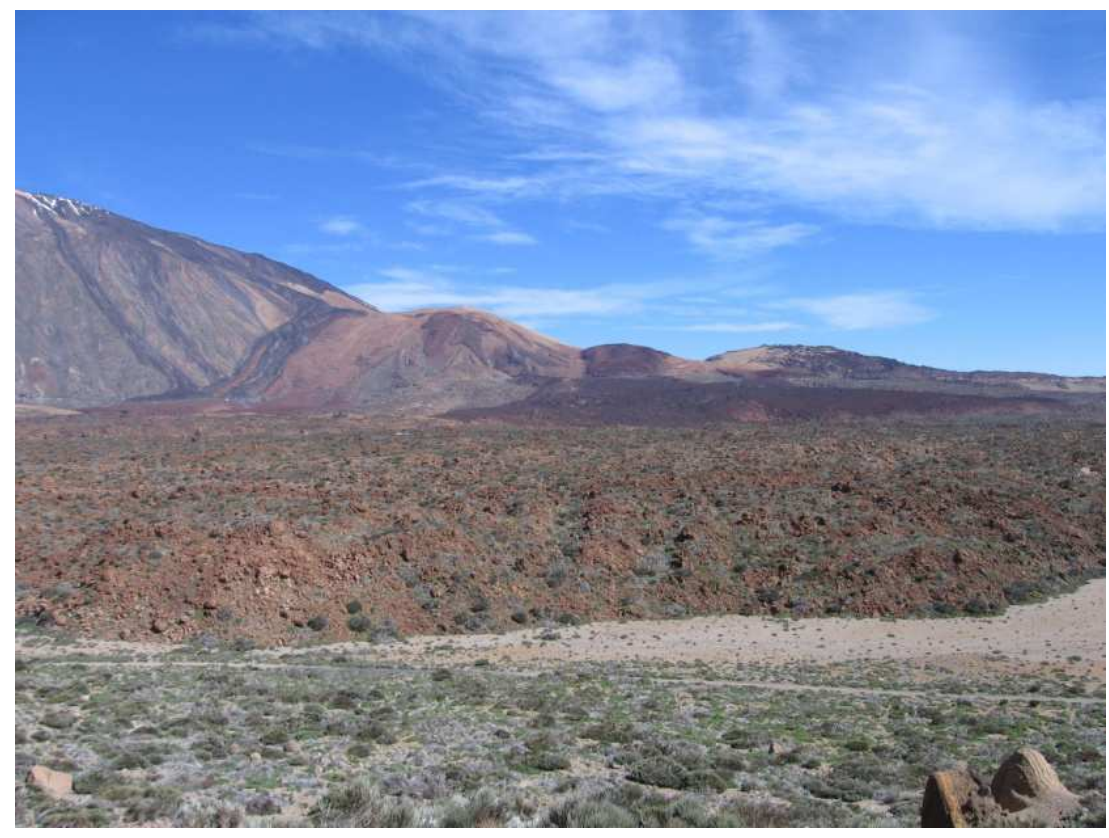

Fig. 6. Caldera filled by repeated ejecta of viscous lava, Pico de Teide 2006, Klarner

As demonstrated by Peterson and Tilling 1980, shear stress plays an important role in the lava type, which is to a large extent driven by the value of the shear strength, and not only by the viscosity. Hence, it is important to understand the paleo-morphology during the volcanic phases in order to predict the possible extent of paleo-volcanics in seismic.

Fig. 7 nicely shows that local lava tongues may reach only a few hundred of meters extent from origin. They are exposed to surface erosion processes and might not have been preserved as geomorphologic relevant features. However, the erosion products will be deposited together with potential reservoir sandstones, leading to a deterioration of their quality mainly in terms of the porosity-permeability properties due to immature components and their products of diagenesis.

\section{Smaller individual cones and lava flows (local events with small vents)}

These individual volcanic features could be seen as remnants of hyaloclastic deposits, explaining the small thicknesses encountered in the exploration wells. They were quickly 
eroded and typical concentric features are left, which can be recognized in the NE of Fig. 8 b. Phreatic and Surtseyan eruptions typically include steam and rock fragments; the extrusion of massive lava is unusual, ashes are distributed by currents. The eruptions can create broad, low relief craters appearing as concentric features. Typical surface features such as spatter cones, ash or tuff cones possess a short life time due to quick erosion. Their remnants can be sedimented with siliciclastics or carbonates. Preservation of ash cones in paleovolcanics seems to be unlikely. The observed concentric features might represent secondary volcanic cones on the flank of bigger complexes, filled with resistant rocks and being preserved over time. This could also explain the number of different smaller lava flows observed in Fig. 8 and 11.

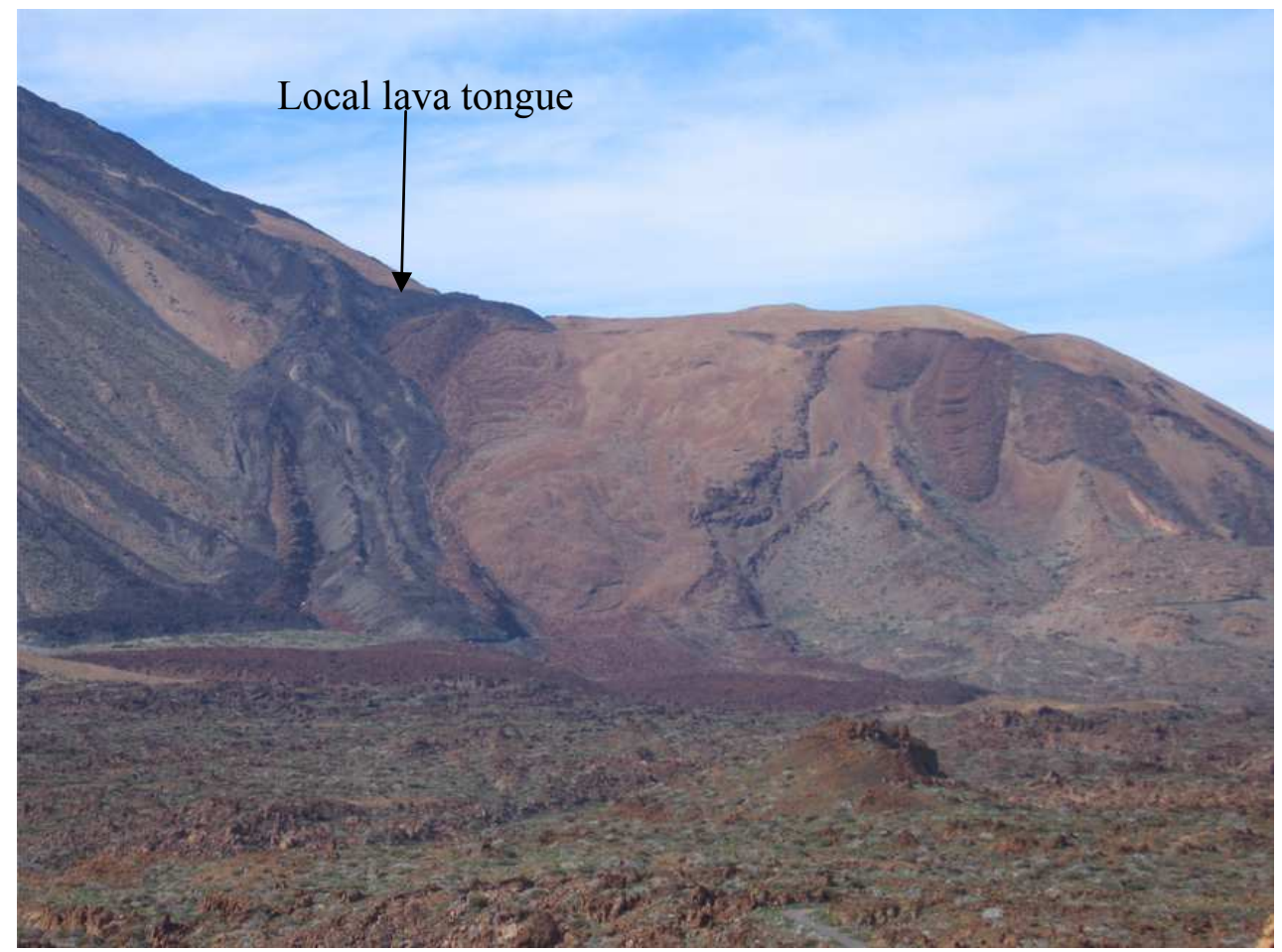

Fig. 7. Local lava tongue, Pico de Teide 2006, Klarner 


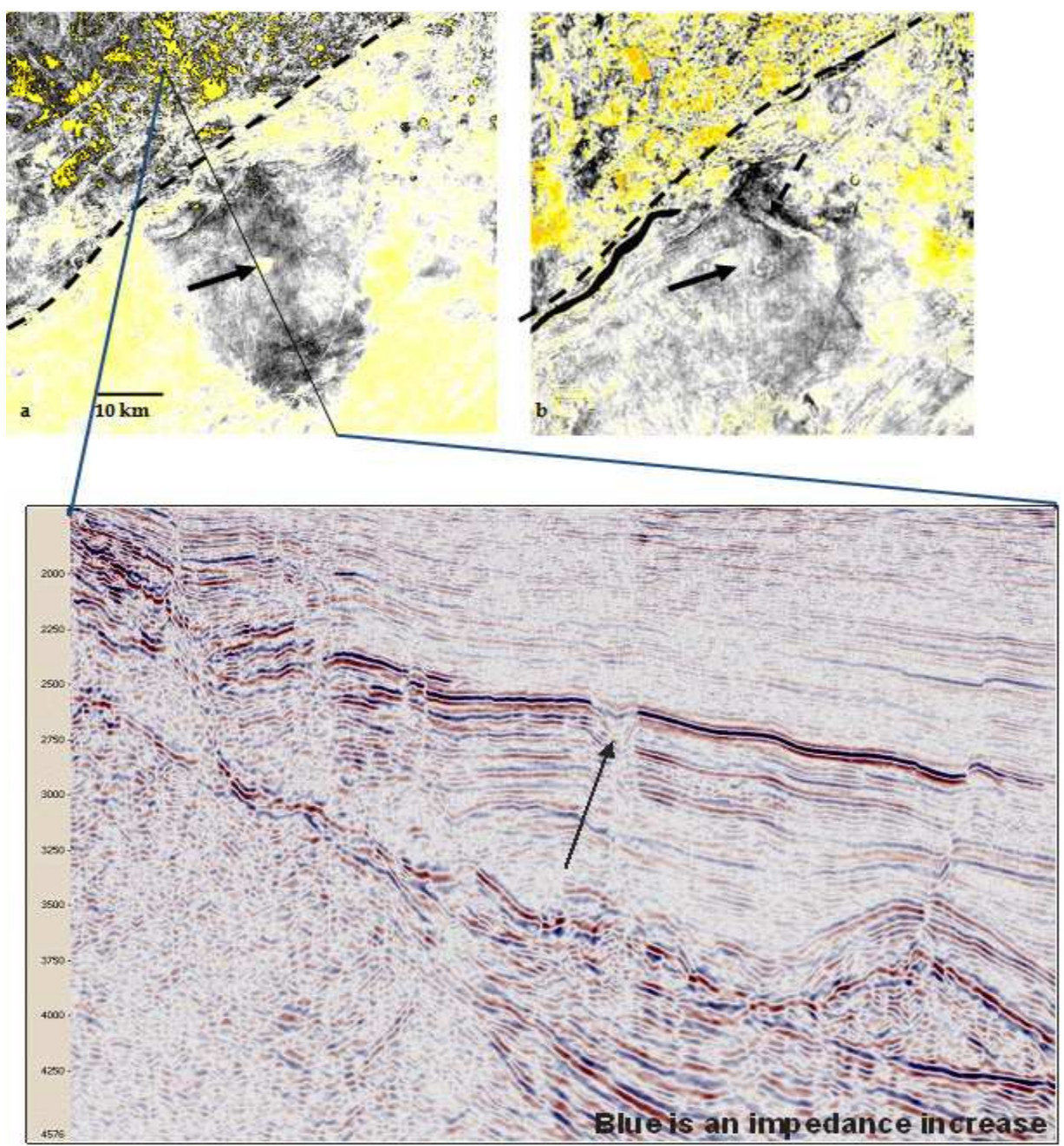

Fig. 8. Amplitude map (a) of the top of a massive $400 \mathrm{~km}^{2}$ basalt flow, indicative of a small mainly subaqueous shield volcano. The dashed line marks the basin hinge line. The arrow indicates the main crater, terminating a deep reaching chimney. In between the seismic layers, representing the volcanic unit, on one of the horizon slices (b), a single channel-like feature can be observed (dashed arrow). As there were no intercalated sediments penetrated, this must be interpreted as an aerial low viscosity lava channel, as they can be observed on dipping flanks of recent volcanoes. Both images show a number of circular features, interpreted as vents and craters

\section{Single dykes as well as dyke and sill complexes.}

Fig. 9 demonstrates the possible density of sills and dykes along the main fault pattern. Sills can develop several levels of occurrence. They can occur as radially symmetrical sill complexes consisting of a saucer-like inner sill at the base with an arcuate inclined sheet or 
as bilaterally symmetrical sill complexes. Both types are sourced by magma diverted from a magma conduit feeding an overlying volcano and can reach considerable distances. Both sill complex types can appear as isolated bodies but commonly occur in close proximity and consequently merge, producing hybrid sill complexes (Thomson and Hutton, 2003).

The spatial density of rocks with higher densities and $\mathrm{Vp}$ velocities can influence the amplitude behavior to a large extent. The occurrence of a sill - dyke complex can substantially deteriorate reservoir properties or lead to complete reservoir extinction in hydrocarbon production. Recognition of sills and dykes on seismic is not an easy task due to their thinness and geological position (Fig. 10).

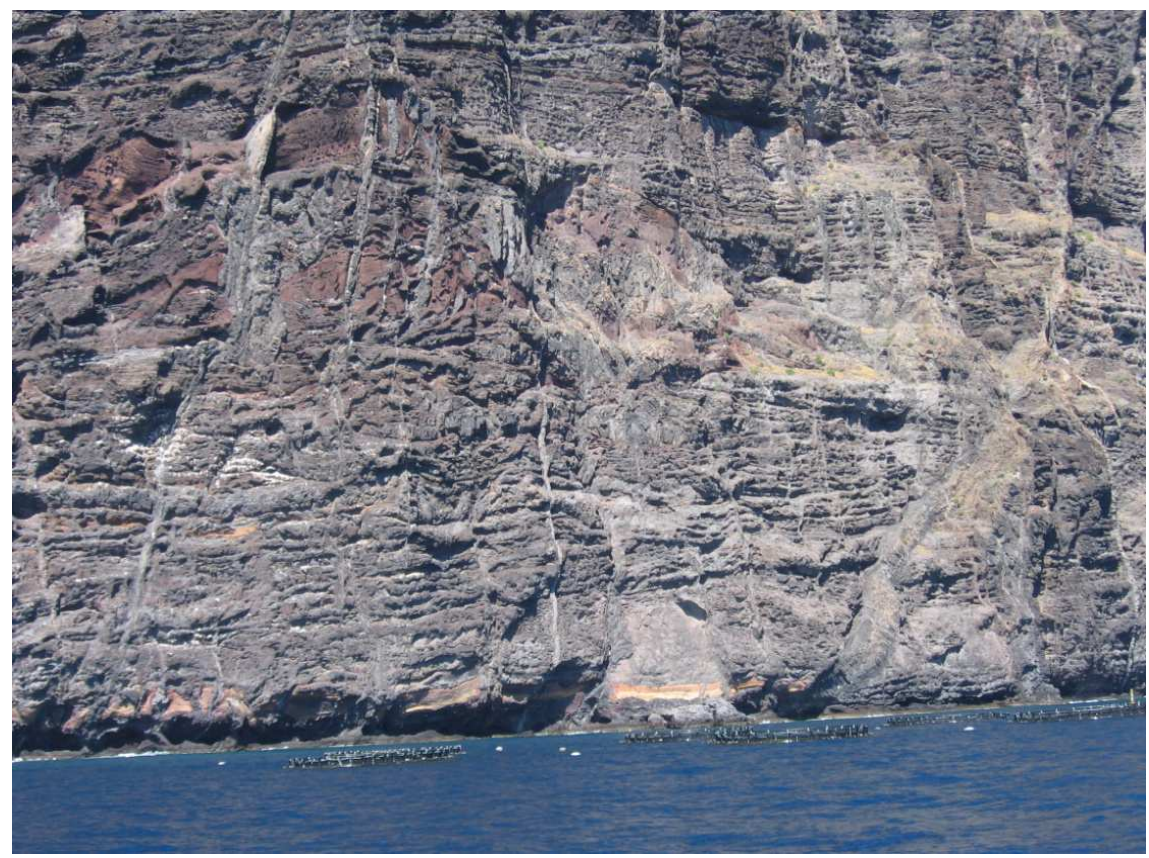

Fig. 9. Sills, laccolites and dykes, NE coast Tenerife, 2006, Klarner
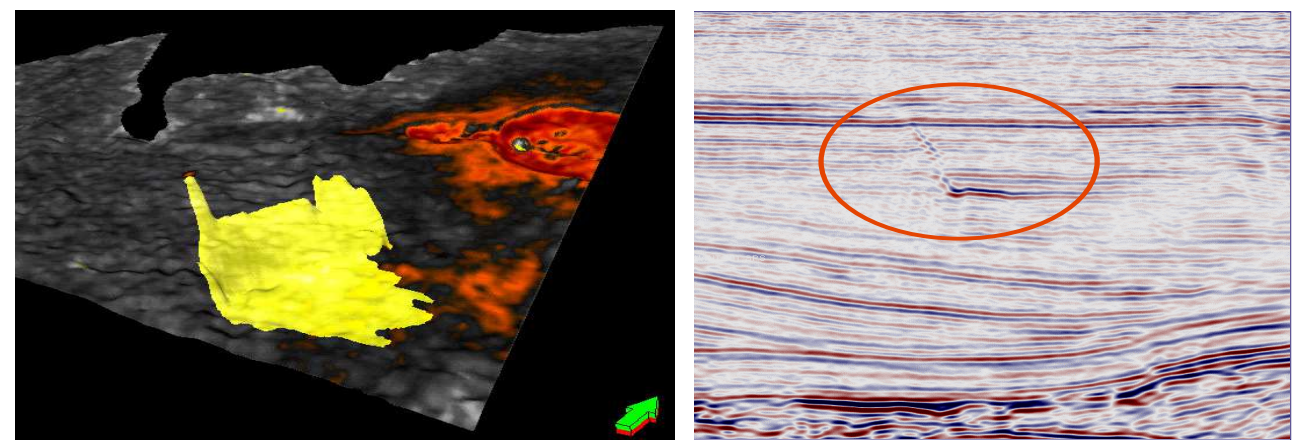

Fig. 10. Image of a dyke, discharging at a depth where a well defined double crater is observed; this implies that both features are fed by the same source 


\subsection{Delineation of structural details by spectral decomposition}

Many of the volcanic bodies show typical crater geometries. A few vents can be traced as chimneys through the section, but many of them could be delineated only by the use of spectral decomposition. Fig. 11 shows an example of several lava complexes being stacked to form a small basalt shield. The older vents are covered by younger lava flows, but can be imaged by spectral decomposition. Spectral decomposition also revealed excellent examples of vent chains, sitting along conduit fractures. This is well demonstrated in Fig. 11 showing two separated centers with lava flows in different directions sourced by the volcanoes, but also from fractures. Size of each complex is about $100 \mathrm{~km}^{2}$.

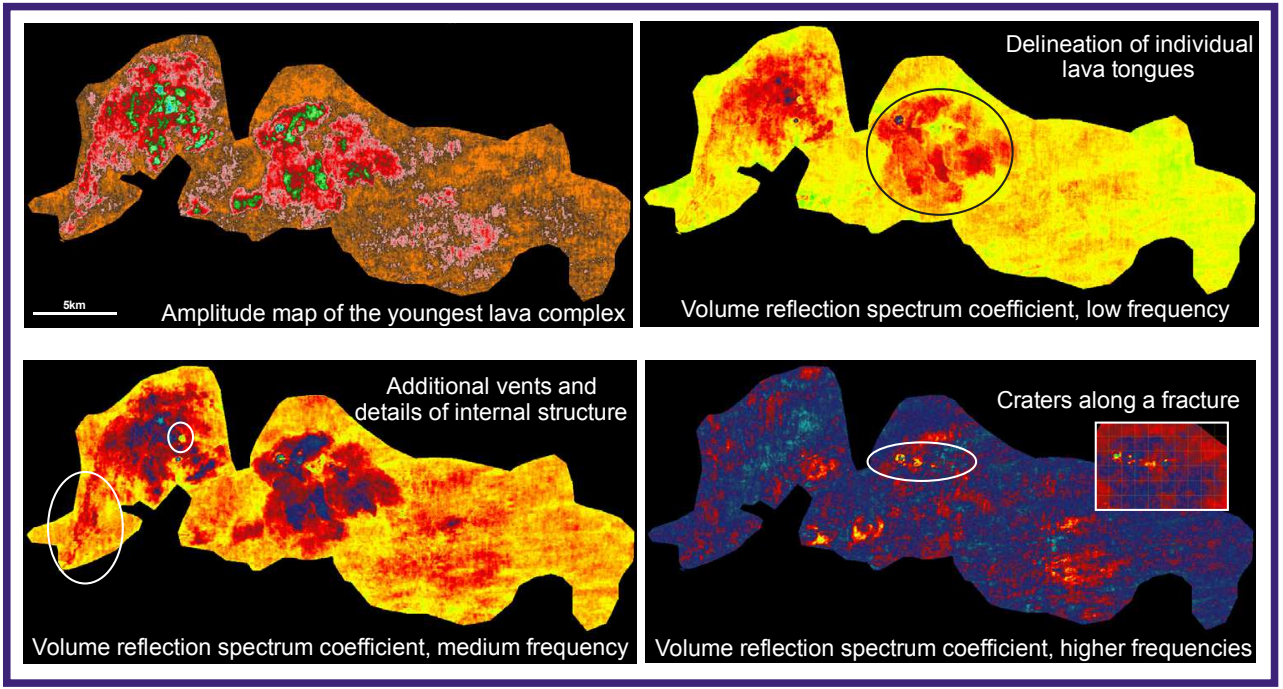

Fig. 11. Examples of spectral decomposition delineating shield volcanoes, lava flows and conduits

The same feature can be visualized by an amplitude image (Fig. 12), displaying a very comparable picture. The volcanic complex is recognizable on the corresponding seismic line. However, an understanding of the true nature of this event is not possible without the applied spectral decomposition and amplitude mapping.

\section{Identification of volcanics using amplitude variations}

\subsection{Elastic rock properties, introduction}

To interpret the seismic amplitude response of different rock types correctly, a sound understanding of their elastic rock properties is required. Seismically effective parameters are the $\mathrm{p}$-wave velocity $\mathrm{Vp}$, the shear wave velocity Vs and the density $\rho$. Physically, these parameters influence the rock's (In)Compressibility $\lambda=f(V p, \rho)$, responding to lithology and pore fluid, the (Un)Elasticity or Rigidity $\mu=f(V s, \rho)$ responding to lithology and the Bulk Density RHOB $(\rho)$, responding to porosity and pore fluid. Commonly used rock properties are the Acoustic Impedance $\left(A I=V p^{*} \rho\right)$ and the Shear Impedance $\left(S I=V_{s}^{*} \rho\right)$, and, derived from them, the $\mathrm{Vp} / \mathrm{Vs}$ ratio (= AI/SI). Quartz sandstones usually are far more 


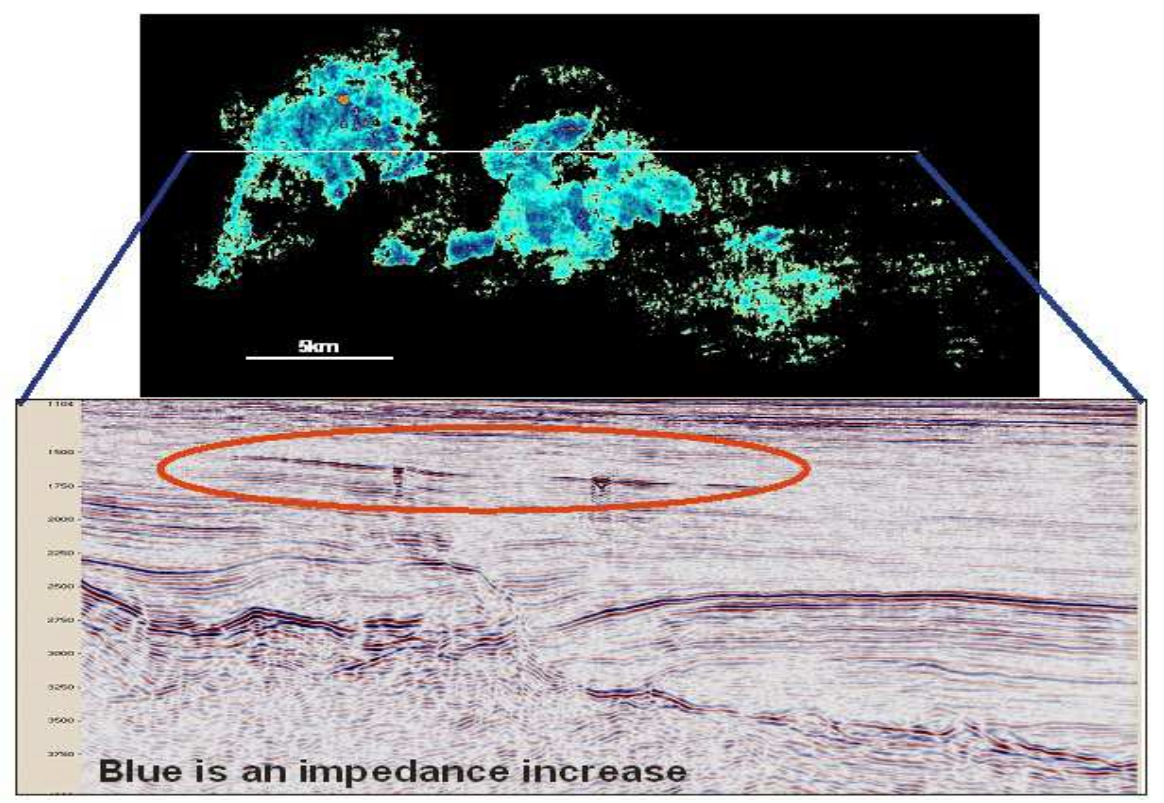

Fig. 12. Amplitude image of the youngest volcanic activity in the area: two sources fed several lava flows through numerous vents and stacked into two small shield volcanoes

compressible then shales, but much less elastic, and in the AI versus $\mathrm{Vp} / \mathrm{Vs}$ ratio cross plot domain the explorationist looks for lithologies with a local minimum indicating hydrocarbon bearing clastic reservoirs. A more detailed description of applied rock physics can be found in Avseth et al (2005). Different types of seismic inversion are used to extract rock properties like $\mathrm{AI}, \mathrm{Vp} / \mathrm{Vs}, \lambda, \mu, \rho$ from seismic data. In this work, we will use AI and $\mathrm{Vp} / \mathrm{Vs}$, as they help to describe the specifics of volcanics and volcaniclastics versus their embedding lithologies.

\subsection{Elastic rock properties, application}

Volcanics display a wide range of physical properties. This is dependent on the chemistry and differentiation stage of the feeding magma as well as on the depositional environment (subaqueous, aerial). In addition, volcanics are mineralogically quite unstable and undergo rapid alteration under the influence of weathering processes and diagenesis. Consequently, they vary in mineral composition and texture. This causes significant differences in the acoustic and elastic behavior. Our understanding of the properties of recently deposited volcanic rocks is becoming better and better but there is a distinct lack of published information dealing with paleo-volcanics, now buried under several kilometers of sediment. However, having worked in different rift related basins around the world, we observe certain trends for the elastic properties of mafic volcanics and related rock types. We are going to show three independent examples to demonstrate this.

\subsubsection{Volcanics from the Sirte Basin, onshore Libya}

In the Hameimat trough (Eastern part of the Sirte Basin), a number of hydrocarbon targeting exploration and production wells at a depth range around $3600-3800 \mathrm{~m}$ have penetrated 
volcanics forming part of a Pre-Upper-Cretaceous (PUC) intracratonic rift system. The actual reservoir consists of quartz sandstones that are syn-rift sediments of the Late Jurassic-Early Cretaceous Sarir Group, deposited in a fluvio-lacustrine paleo-environment (Ottesen et al. , 2005). To compound the problem, fluvial sandstones have in parts been invaded by a variety of extrusive basalts and intrusive dolerites, but also volcaniclastic facies types, related to lahar flows confined by the fluvial depositional system. The goal of several reservoir characterization studies was to quantify critical reservoir properties and to identify the occurrence of non reservoirs, such as the volcaniclastics. In 2002, De Vincenzi et al. reported that for some of the basalt varieties their high acoustic impedance was a physical differentiator that could be used to identify them from seismic data (Fig. 13).

By cross plotting all available petrophysical data at well locations they established subtle relationships between porosity and acoustic impedance. The volcanics are characterized by extremely low porosities (between 0.5 and $5 \%$ ). The pay zone exhibits average porosities between 9.1 and 11. 6 percent; single units can reach 14\%. A significant number of basaltic layers cross plot with clearly higher acoustic impedances than all other lithologies. Seismic response modeling was carried out to verify whether or not the thickness of the individual basaltic layers would be large enough to allow a seismic resolution of this lithotype. Timemigrated seismic data were transformed into their principal components within the target time window and a number of seismic attributes were extracted. Using neural network algorithms in commercially available software, a number of independent workflows for seismic waveform clustering were tested both for unsupervised and supervised classifications, as well as for the supervised property (porosity) prediction. The synthetic impedance traces showed that especially the basaltic layers could be identified at least qualitatively at the reservoir level. This in turn allowed searching the seismic for basaltic rock types.

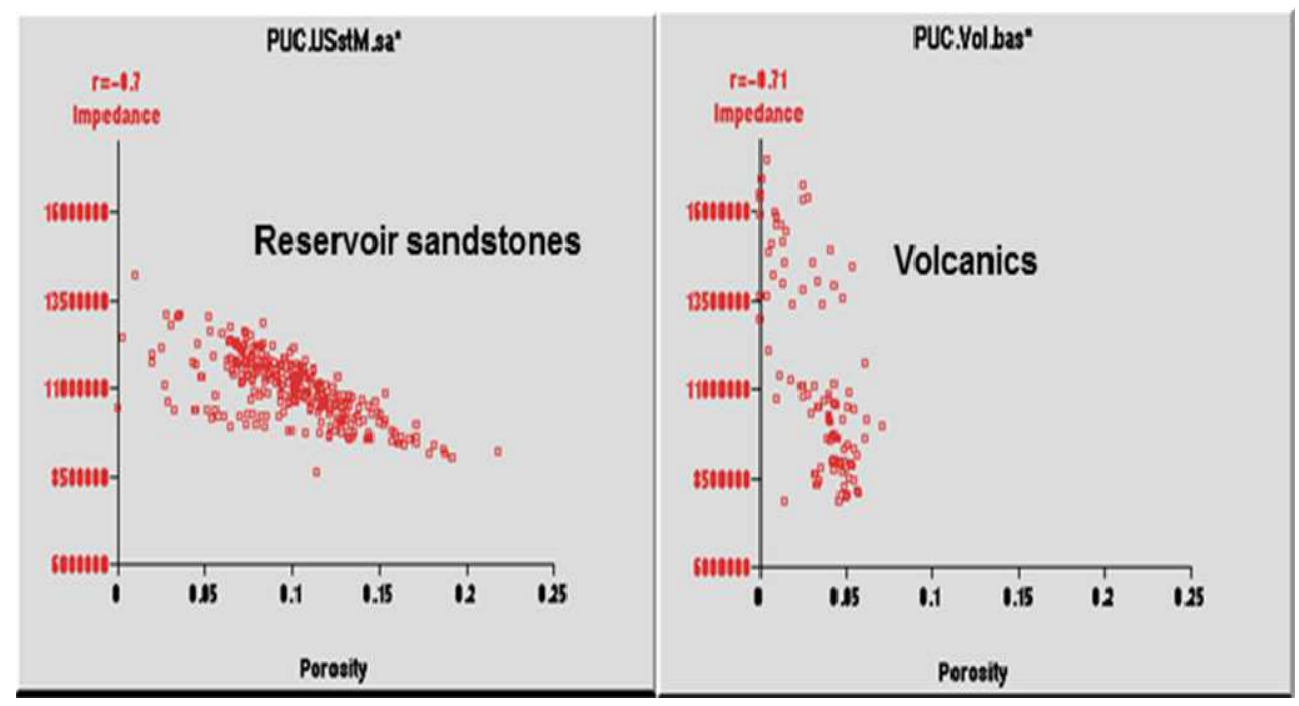

Fig. 13. Cross plots Porosity versus Acoustic Impedance; right - reservoir sandstones; left volcanic (high impedance basalts and low impedance lahar type volcaniclastics) 
Seismic data were inverted into a cube of acoustic impedance, and by the use of a neural network algorithm transformed into average porosity. Using the correlation of acoustic impedance and porosity, within the reservoir section we identified areas with very low average porosity (Fig. 14), interpreted as indicating presence of volcanic lithofacies types (basalt, dolerite). The data also demonstrate that the amplitudes interpreted as volcanics seem to follow a trend parallel to the main fault direction. Therefore, a deep seated fault is interpreted to have served as a conduit for the magma.

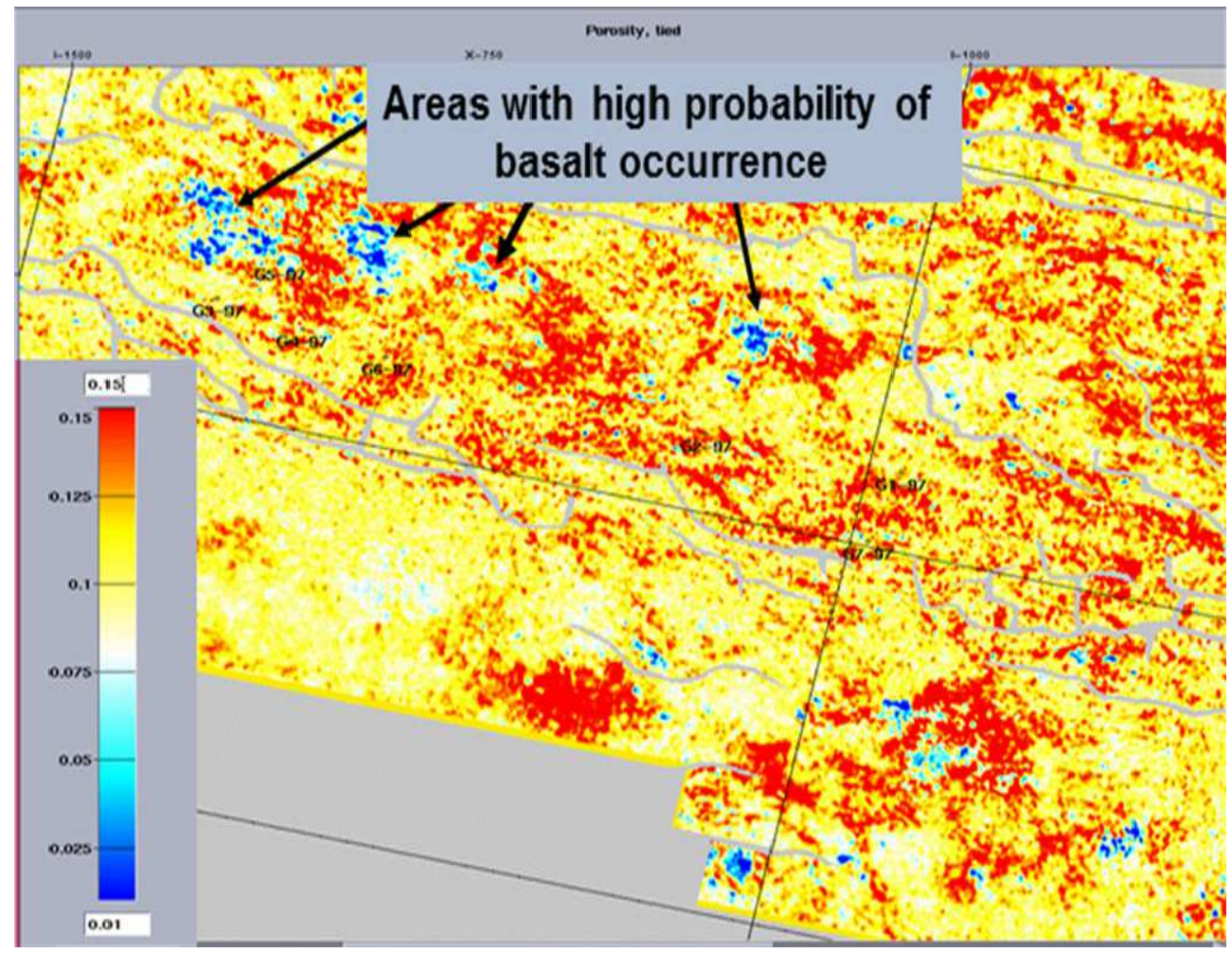

Fig. 14. Supervised porosity prediction (in volume fractions) from acoustic impedance data; in blue: supposed volcanics

However, the low impedance lahar flows encountered in one of the wells could not be separated from the porous reservoir sandstones using impedance data alone. We had to look for an additional parameter, distinguishing the reservoir from non-reservoir units. Some of the elastic parameters are presented in Fig. 15. We can clearly see that the volcanic facies types (pink and purple dots) exhibit high density, but also a broad scatter for the Pwave velocity, partially overlapping with the reservoir sandstones (orange dots). Especially the lahar rock type covers the same impedance range as porous reservoir sandstone.

Nevertheless, we see a clear separation in the $\mathrm{Vp} / \mathrm{Vs}$ domain: both volcanic facies types exhibit very low shear wave velocities (compare Hanitzsch et al. 2007, who then used this parameter for the application of dual inversion applied to 2D multi-component seismic data 
onshore Libya). Interestingly, the volcanics seem to follow the empirical trend for $\mathrm{Vp} / \mathrm{Vs}$ established by Greenberg and Castagna (1992) for limestones.
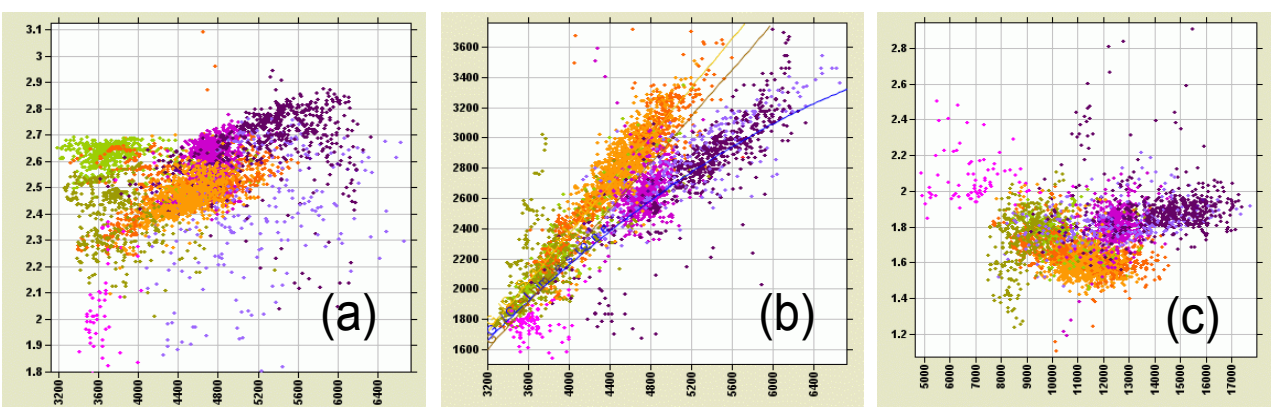

Fig. 15. Cross plots of various physical parameters for different lithotypes from the Sirte basin: orange - quartz sandstones; green - shales; pink - volcaniclastics/lahar flows; purple - basalt. (a) p-wave velocity ( $\mathrm{m} / \mathrm{s}$, horizontal axis) versus density $\left(\mathrm{g} / \mathrm{cm}^{3}\right.$, vertical axis); (b) $\mathrm{p}$-wave velocity $(\mathrm{m} / \mathrm{s}$, horizontal axis) versus shear wave velocity $(\mathrm{m} / \mathrm{s}$, vertical axis) with Greenberg-Castagna's empirical trends for sandstones (orange), shale (brown) and limestone (blue); (c) acoustic impedance (horizontal axis) versus $\mathrm{Vp} / \mathrm{Vs}$ ratio (vertical axis)

\subsubsection{Volcanic example from the Central North Sea}

Another example of elastic parameters is demonstrated for Jurassic volcanics from the North Sea. Graverson (2006) gave a comprehensive overview for the evolution of the JurassicCretaceous Rift Dome in the Central Graben in the North Sea. A few exploration wells, targeting Jurassic sandstones for hydrocarbon exploration, encountered both, Mid-Jurassic basalts and Mid-Jurassic tuffites. We can look at their elastic properties using data from block 15/22, representing a depth range from 3000 - $3200 \mathrm{~m}$ (Fig. 16).
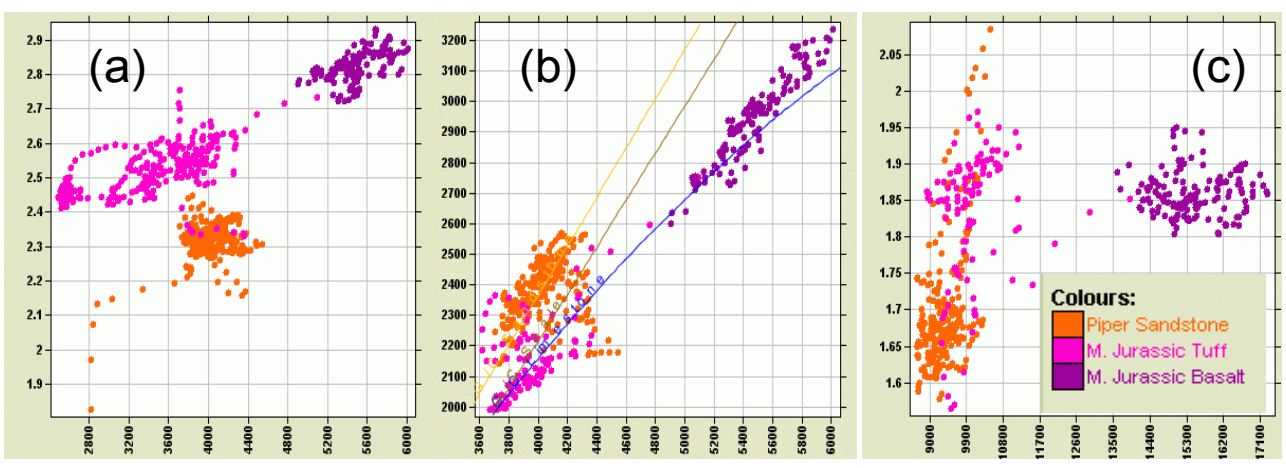

Fig. 16. Cross plots of various physical parameters for different lithotypes from the Central North Sea: orange - quartz sandstones; pink - volcaniclastics/tuffites; purple - basalt. (a) pwave velocity ( $\mathrm{m} / \mathrm{s}$, horizontal axis ) versus density $\left(\mathrm{g} / \mathrm{cm}^{3}\right.$, vertical axis); (b) p-wave velocity $(\mathrm{m} / \mathrm{s}$, horizontal axis) versus shear wave velocity $(\mathrm{m} / \mathrm{s}$, vertical axis) with Greenberg-Castagna's empirical trends for sandstones (orange), shale (brown) and limestone (blue); (c) acoustic impedance (horizontal axis) versus $\mathrm{Vp} / \mathrm{Vs}$ ratio (vertical axis) 
The pore fluid of the Jurassic sandstone has been substituted to water using the Gassmann fluid substitution algorithm to ensure that we only look at rock properties (comp. Smith et al. 2003). We can see again, that the volcanic rock types have a higher density then the porous reservoir sandstone, but at least the volcaniclastics overlap again in the p-wave domain. The basalts can be identified by their high acoustic impedance. For the tuffites we need the $\mathrm{Vp} / \mathrm{Vs}$ ratio as the discriminating physical property. The relatively slow shear wave velocity is also typical for the encountered basalts, and as in the North African example the shear wave can be rather well approximated using the empirical limestone trend from Greenberg-Castagna.

\subsubsection{Volcanics from the Santos Basin offshore Brazil}

The Santos Basin provides a unique setting for the investigation of paleo-volcanics and their interaction with the embedding sediments. Although a number of wells along the basin hinge line have penetrated Upper Cretaceous basalts, only few of them have had a shear sonic log acquired. Examples from those wells have been included in the current study, showing volcanics from a depth range of $3200-4600 \mathrm{~m}$.

The heterogeneity of the volcanics produces a wide scatter of petrophysical properties. Looking at the cross plots in Fig. 17, we can observe several trends in the acoustic and elastic properties: Different basalt units are compact, non-weathered volcanics and show higher impedances than the clastic lithologies. Weathered and/or re-deposited basalts (shown in purple) may have lower impedances, mainly due to far lower velocity values. But both types show high $\mathrm{Vp} / \mathrm{Vs}$ ratios, distinguishing them from most of the clastic sediments. There is a group of sandstones (orange colors) that also exhibit high $\mathrm{Vp} / \mathrm{Vs}$ ratios. It has been shown that these sandstones contain a high amount of volcanic rock fragments that are erosional products from the basalts nearby (Klarner et al 2005, 2008). Fortunately, this sandstone type shows significantly lower impedances than all other types of lithology and in this case will produce softer reflections than the basalts.
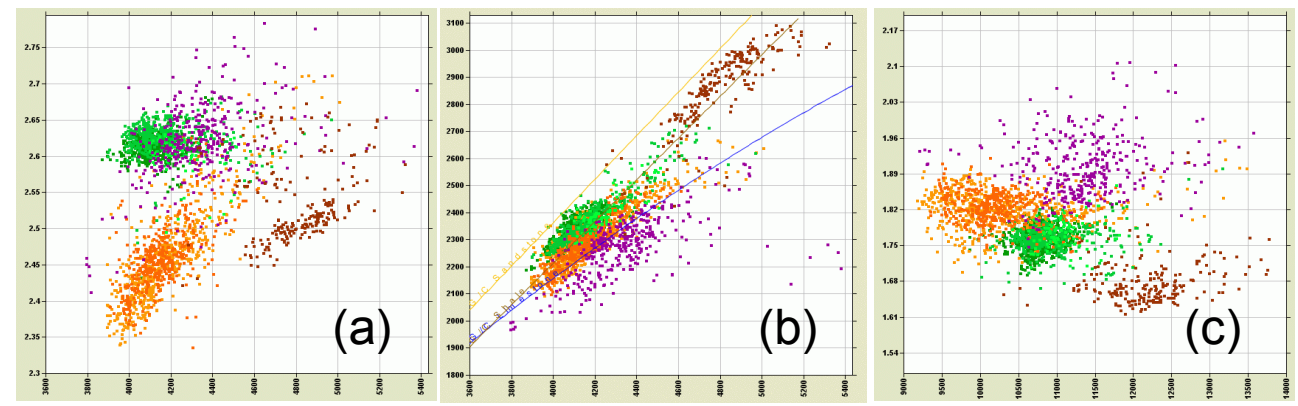

Fig. 17. Cross plots of various physical parameters for different lithotypes from the Santos basin: brown - reservoir sandstones; orange - sandstones with a high percentage of redeposited volcaniclasts; green - shales; purple - basalt. (a) p-wave velocity (m/s, horizontal axis) versus density (g/cm3, vertical axis); (b) p-wave velocity (m/s, horizontal axis) versus shear wave velocity (m/s, vertical axis) with Greenberg-Castagna's empirical trends for sandstones (orange), shale (brown) and limestone (blue); (c) acoustic impedance (horizontal axis) versus $\mathrm{Vp} / \mathrm{Vs}$ ratio (vertical axis) 
The cross plot of Vp versus Vs in one of the wells (Fig. 17) shows that the volcanics (in this case diabase/dolorite and volcanic breccia) exhibit $\mathrm{Vp} / \mathrm{Vs}$ ratio similar to a typical limestone. The thin section analysis and FMI data show that the wells encountered basalts and their weathering products the chemical composition comprising (Fig. 18): silicified vitreous alkali olivine basaltic rocks; olivine alkali dolerite (diabase); pebbly volcanic conglomerate; volcaniclastic litharenite.
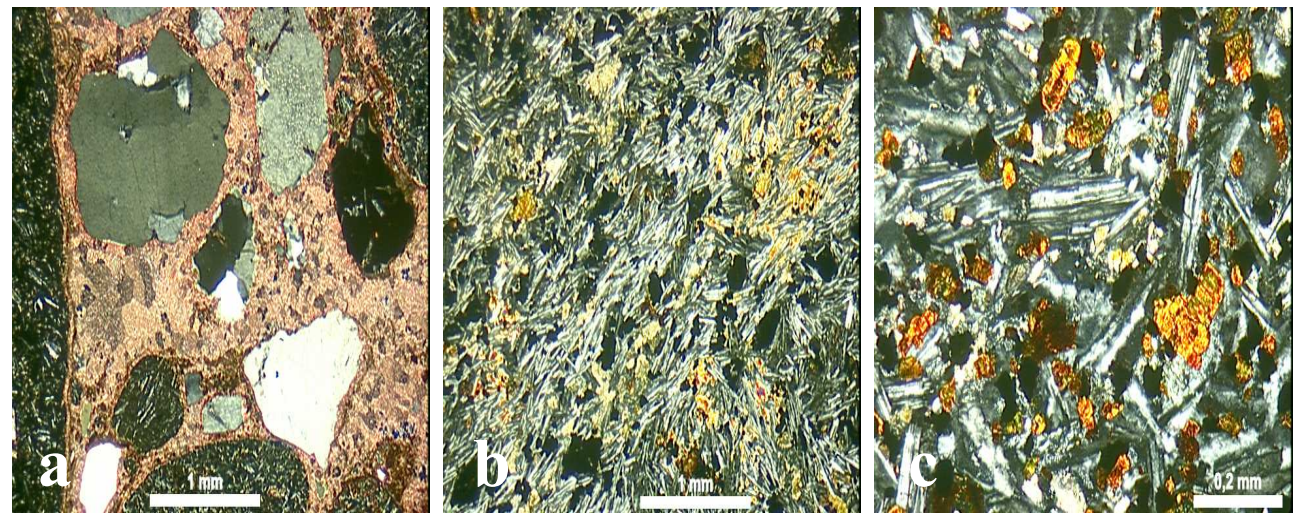

Fig. 18. Thin section images of different Upper Cretaceous volcanic rock types from the Santos Basin: (a) conglomerate with fragments of volcanic and non-volcanic rocks, cemented by displacive calcite, (b) dolerite (diabase) with trachytoidal texture, (c) olivine basalt with intergranular texture of reddish altered olivine crystals

\subsection{Elastic rock properties - conclusions}

All the investigated volcanic rock types show a broad scatter of acoustic properties. Whereas tight basalts and dolerites may exhibit high acoustic impedances and, thus, may stand out on the seismic amplitude section, there are numerous examples of volcanics (weathered basalts, hyaloclastic rocks, tuffites, lahar deposits etc), which overlap with reservoir sandstones in the acoustic impedance domain. Measured velocity ranges from over 3000 $\mathrm{m} / \mathrm{s}$ to over $6000 \mathrm{~m} / \mathrm{s}$ (Fig. 19 left). As to be expected for magmatic rock types with their heterogeneous internal structure and texture, we do not see a depth dependent (compaction) trend for velocity for any of the lithotypes (Fig. 19 right).

However, all investigated volcanic lithotypes show a distinct shear weakening compared to average clastic rocks, and the ratio of p-wave velocity to shear-wave velocity is abnormally high - in many cases comparable to limestones. This is valid for all investigated volcanic lithotypes and can be used for prediction of shear wave velocity from p-wave velocity in cases where no shear log information is available. Only for very high velocities, the volcanics diverge from the empiric Greenberg-Castagna trend for carbonates, and can be described by the linear regression

$$
\mathrm{Vs}=0.51 \mathrm{Vp}+148(\mathrm{R}=0.86) \text { in } \mathrm{m} / \mathrm{s}
$$

Looking at the thin section images, we currently believe that the commonly observed extremely low shear velocities for all investigated volcanic related rock types are mainly a 
texture effect: the microcrystalline fabric of the volcanics as well as the chlorite-calcite matrix of the volcaniclastics react in a similar way to the microcrystalline matrix in carbonates.
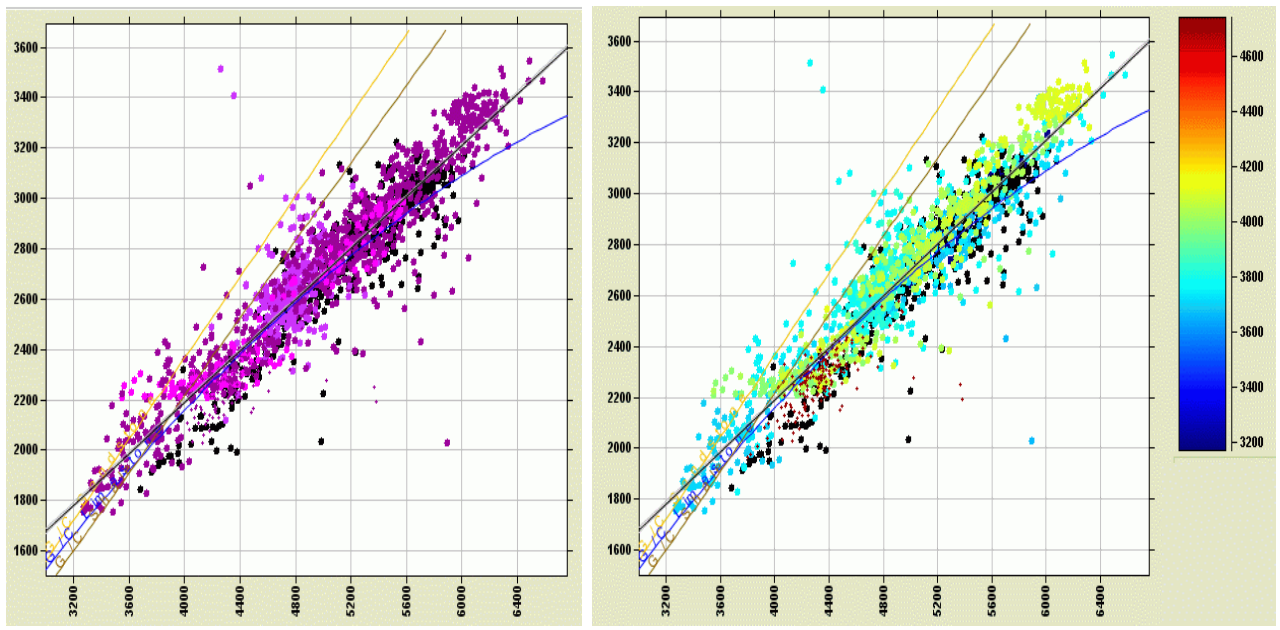

Fig. 19. P-wave velocity $(\mathrm{m} / \mathrm{s}$, horizontal axis) versus shear wave velocity $(\mathrm{m} / \mathrm{s}$, vertical axis) for volcanic from well data from different regions (Central North Sea, Sirte basin onshore Libya, and Santos Basin offshore Brazil). Left: different lithotypes (pink volcaniclastics, purple - basalt); right: depth of penetration in $\mathrm{m}$. The linear correlation is $\mathrm{Vs}=0.51 \mathrm{Vp}+148(\mathrm{R}=0.86)$

\subsection{Amplitude behavior}

Although the impedances cover a wide range of values, the individual volcanic bodies identified in the seismic mostly appear as strong bright hard reflectors. If carbonates are not involved, a basalt body can be traced by its significantly higher $\mathrm{Vp} / \mathrm{Vs}$ ratio compared to other lithology types. This is especially important when we deal with weathered basalts which show a lower density and therefore lower impedance. Our interpretation is also confirmed by the occurrence of typical volcanic geometries which are found in the specific tectonic context of a rift basin. Some of the individual bodies could be misinterpreted as the top of a carbonate cemented delta or terminal lobe or are reminiscent of fluvial channels. But the sum of the observed features within the given tectonic setting, including chimneys, craters, stacked lava flows and dykes gives us confidence in classifying these geometries as being volcanic in nature.

\subsubsection{AVO analysis}

In hydrocarbon exploration, AVO analysis is a common tool used for better understanding the lithology and the pore fluid of potential oil and gas bearing reservoirs. AVO means analysis of amplitude changes with offset, e. g. with the distance from the seismic energy source. Very often a high porosity gas or oil charged sandstone reservoir, due to a very low $\mathrm{Vp} / \mathrm{Vs}$ ratio, shows a soft reflection, increasing with offset, whereas the embedding lithology, such as shales or brine sands, may dim out due to the dispersion of the wave energy. Therefore, the seismic interpreter compares the amplitudes at different offsets from 
the source to identify potential anomalies. To enhance the data, selected offset ranges are usually stacked into so called angle stacks. Detailed explanations of the method can be found in Castagna et al. (1993) and many other publications.

Due to their anomalously high $\mathrm{Vp} / \mathrm{Vs}$ ratio when compared with other lithologies, acoustically hard volcanic layers also usually show amplitude strengthening with offset. At shallower levels $(\sim 2,000 \mathrm{~m})$, we can observe an absolute increase of the positive amplitude related to the top of the basalt. At greater depths $(>3,000 \mathrm{~m})$ the amplitude with offset dims much less than the background and we still observe a relative amplitude anomaly. This effect, being observed from the interface sediment-basalt and basalt-sediment, can be stronger than any variation (lithology or fluid) within the clastic section. Fig. 20 shows an example of an AVO model from a location in the Santos basin demonstrating this effect: both reflections top and bottom of the basalt layer - show an absolute increase of amplitude with increasing distance from the energy source.

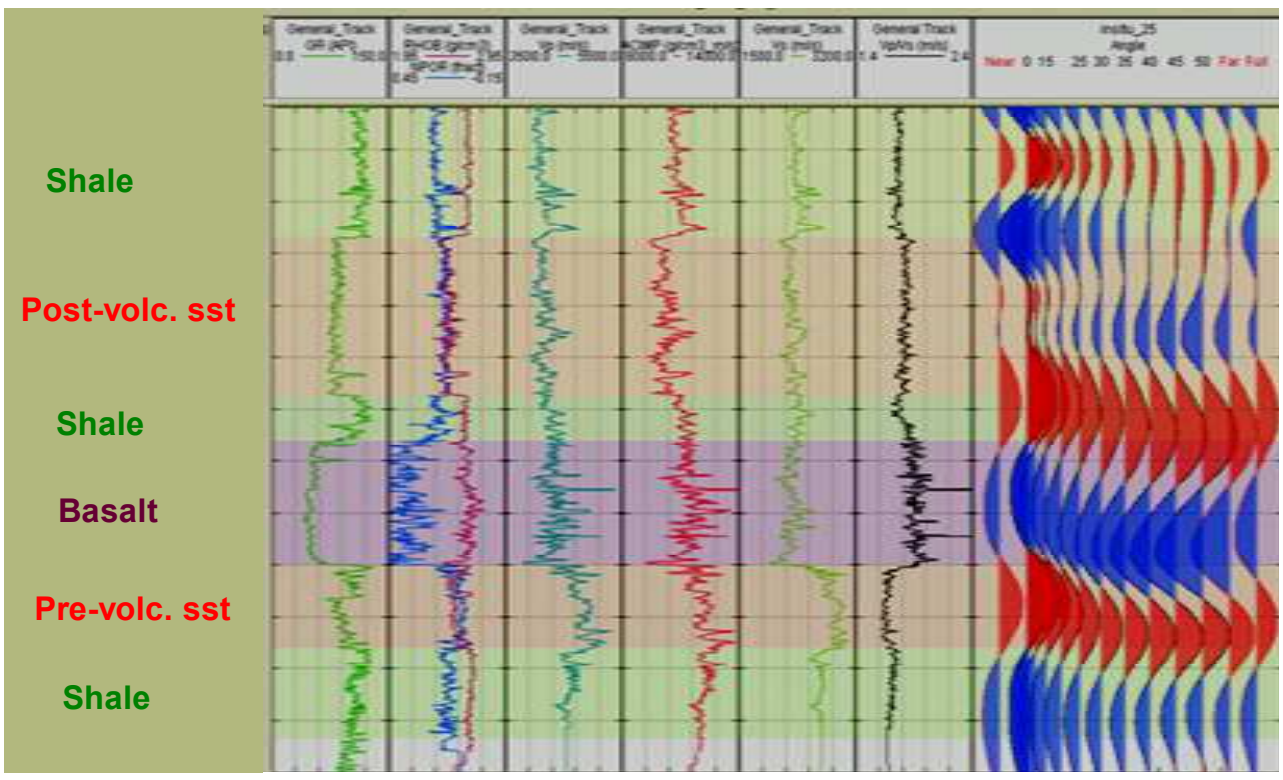

Fig. 20. Demonstration of the AVO behavior (strengthening of amplitude with increasing incidence angle) at top and bottom of a basalt reflection

A real seismic example is seen in Fig. 21. On the Near angle stack we see a prominent reflection (red is the positive polarity top of the geobody, meaning an increase in impedance, black the negative polarity bottom), which becomes stronger on the Mid and on the Far angle stack, whereas the embedding clastic lithology on the section dims out. The 3D image of this reflection reveals a geobody, interpreted as a volcanic event: we see a vent (circular feature), from which a number of stacked lava tongues discharged. The whole geobody extends over an area of about $5 \times 5 \mathrm{~km}$.

Based on the AVO response of lithologies with anomalous values of Vp/Vs ratio, Gidlow \& Smith (1992) developed the so called fluid factor approach. The Fluid Factor attribute is based on the deviation of analyzed points from a background mudrock line that should be 
locally derived from the given data set. Negative values mean that due to the low $\mathrm{Vp} / \mathrm{Vs}$ ratio the deviation is into the negative intercept - negative gradient direction, which is typical for hydrocarbon bearing sandstones. An example for a gas bearing sandstone is represented in Fig. 22. For our volcanics, the high $\mathrm{Vp} / \mathrm{Vs}$ ratio means that we see a deviation from the background towards positive intercept and positive gradient, hence a positive fluid factor. Similar observations have been reported by Dillon et al (2004), where they compared the strong positive feature on the Fluid Factor Stack at the top of a volcanic layer to carbonate response. Again, we have to use the amplitude geometry to distinguish between carbonate and volcanic response.
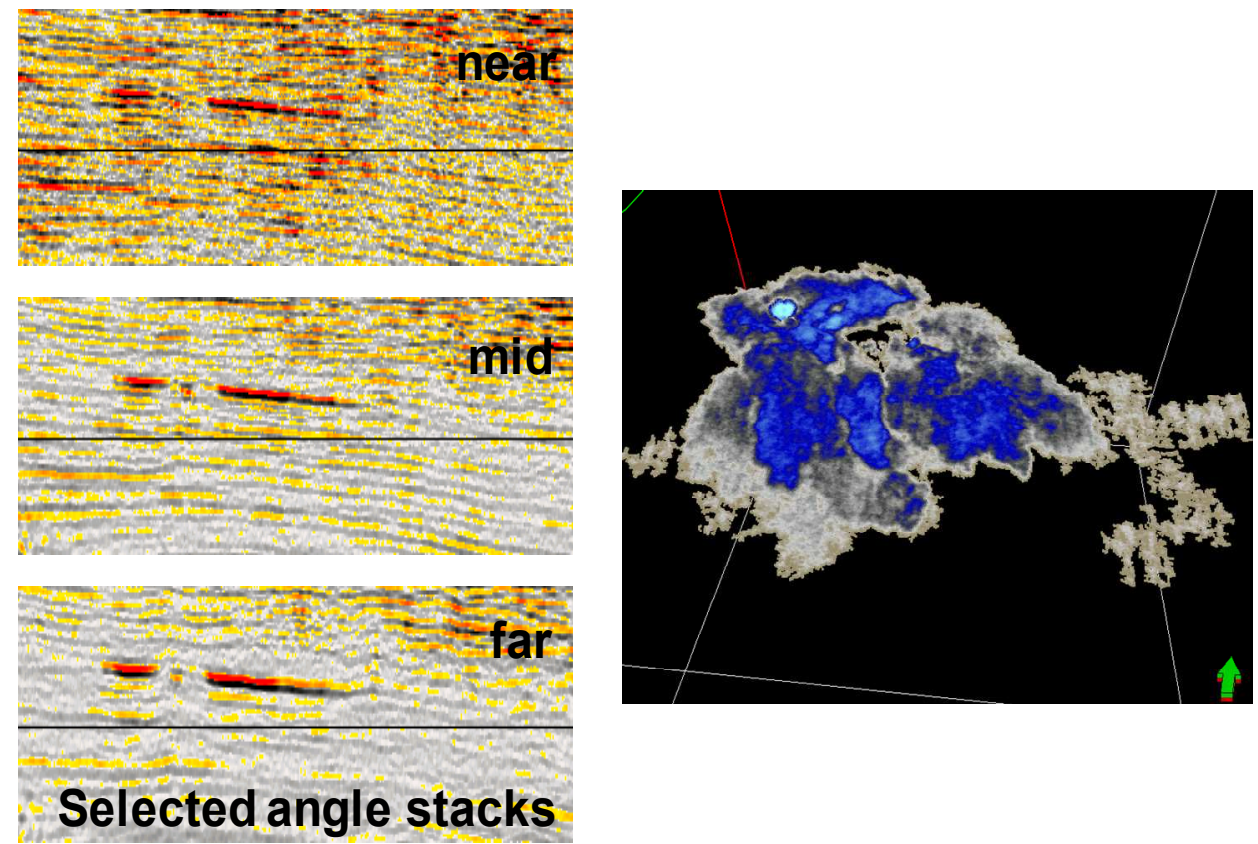

Fig. 21. The images of a volcanic layer on different seismic attributes: Near, Mid and Far Angle Stack (left); 3D amplitude image of the Full Angle Stack Amplitude (blue is a positive reflector)

Another useful tool to discover high $\mathrm{Vp} / \mathrm{Vs}$ ratios relative to a regional background trend is the simultaneous inversion of different angle stacks. The output is usually cubes of acoustic impedance, shear impedance and, in the case of good data quality, density, which can be converted to additional products like the $\mathrm{Vp} / \mathrm{Vs}$ ratio. We do not show an example here, but the method is a proven industry tool for lithology classification and shows similar results to those demonstrated in Fig. 22.

\subsection{Implication for hydrocarbon exploration}

The economic impact of volcanic rock types for the geology of fields and prospects in many exploration and production areas is tremendous: in the past, partial or complete reservoir substitution, complex diagenetic alteration by circulating hot fluids and addition of mineral components have led to alteration of rock properties and misinterpretation of seismic data. 

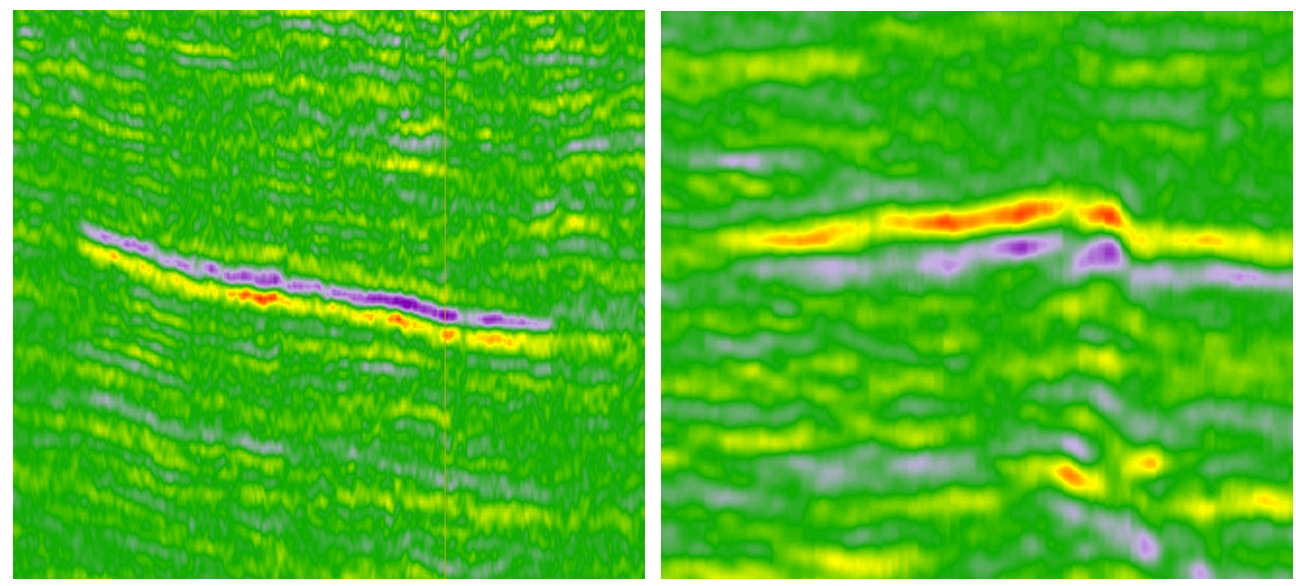

Fig. 22. Fluid factor stacks of the basalt layer shown in Fig. 21 (left) and a gas bearing sandstone layer (right). Purple is a positive deviation from the greenish background trend, orange is a negative deviation

On the other hand, fractured mafic intrusions are either acting as a reservoir, or have thermally cracked the embedding lithology, making it a producing reservoir, as in the Filon example in Argentina (compare Ortin et al. 2005).

In addition, volcanic rocks may form migration barriers, working both in our favor and against us: non-permeable volcanic layers can seal the top of the reservoir, preventing it from breaching, or they can build a migration barrier for the fluid on its way from the source rock into the trap.

We encountered Rotliegendes, Jurassic, Cretaceous and partially Tertiary volcanics in areas of interest in Argentina, Brazil (Fig. 23), Libya, Northern Germany and the Dutch offshore, UK North Sea. Colleagues report presence of volcanics in E\&P projects offshore Australia (O'Halloran et al. 2001), onshore China (Zhao et al. 2002; Wu et al. 2006, Yang et al. 2008), and in Mexico (Pena et al. 2009), to name only a few.

The majority of rock physics publications on clastic reservoirs deal with the properties of subfacies in the sand(stone) - shaly sand(stone) - sandy shale - shale environment, where grain-supported quartz sandstones, representing one of the end members of the succession, are well understood. The elastic properties of shales are the current focus of a number of research groups. Based on generalized velocity-porosity models calibrated to local well data, theoretical models and empirical relationships help us to understand the seismic facies, to calculate missing logs and to predict the bulk properties under reservoir conditions.

However, in many basins around the world, much more complex lithologies are encountered. Synsedimentary volcanic activity and its erosional products may lead to a complex mineralogy, including volcanic rock fragments, and consequently to a very complex diagenetic history. As a result, the texture and thus the elastic properties of the rocks are affected. Known relationships between P-wave velocity and S-wave velocity are not applicable. Instead, anomalously low shear velocities may lead to $\mathrm{Vp} / \mathrm{Vs}$ ratios for sandstones that are higher than in the bounding shales, and the seismic response may be very specific. 


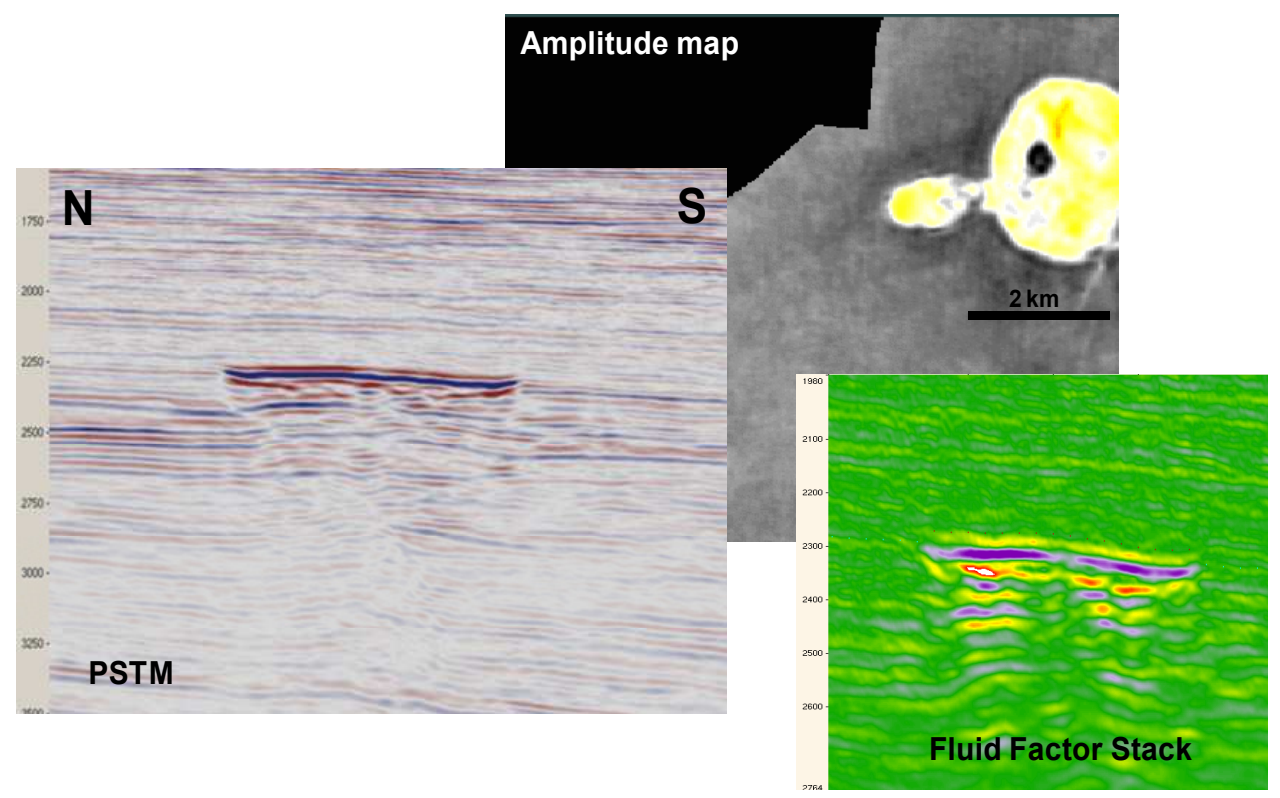

Fig. 23. Another example of amplitude expression, geometry and AVO response of a volcanic feature

One of the most important implications for seismic amplitude interpretation of the presence of rift volcanics in the sedimentary section is the fact that the erosional products from unstable volcanic rocks tend to contaminate the reservoir sandstones in the nearer and wider vicinity. Wind and water spread the particles around, mixing quartz and acid feldspar grains with mafic elements, thus completely changing the mineralogy of the sediment and subsequently causing different diagenetic alterations. A perfect example has been described from Cretaceous reservoirs offshore Brazil in Klarner et al. (2008). The prevolcanic sandstones - an arkose with about $50 \%$ quartz content, $14 \%$ detrital feldspar grains and $4 \%$ volcanic rock fragments, classification after Folk (1968) - in the thin section images showed up as a grain supported stiff rock, showing the typical low Vp/Vs ratio compared to the embedding shales. It is represented by brown dots in Fig. 17. The post-volcanic sandstone had much less quartz (30\%), 13\% volcanic rock fragments and the grains were embedded into a pseudo matrix of secondary chlorite and calcite. The rock (represented in Fig. 17 by orange dots) exhibits relatively low velocities and an extremely high $\mathrm{Vp} / \mathrm{Vs}$ ratio, with the inherent risk of pitfalls for AVO interpretation.

Similar phenomena have been observed and reported for some Tertiary turbidities offshore Sakhalin (Klarner et al. 2009) and in the Triassic section of the Barents Sea (Polyaeva et al. , 2011).

It is therefore crucial to understand the distribution of these volcanics in and around the reservoir. 3D seismic can be extremely helpful, if well understood.

\section{Conclusions}

Examples in the literature, dealing with volcanics and volcanic related rock types on seismic data used for exploration and production of hydrocarbons are still rare. There has been a lot 
of activity centering upon sub-basalt imaging, but this does not really help to overcome the problems we have in identifying and predicting volcanics from 3D seismic data at reservoir level. AVO investigations have typically concentrated on sandstone-shale intercalations and carbonates. The pure visual identification of volcanics within the seismic is very difficult. Either they appear to be similar to carbonates (basalts) or to siliciclastic rocks (volcaniclastics). However, due to the different acoustic and elastic properties of clastic and carbonate reservoir rocks versus volcanics, there is a realistic chance to develop an approach for the identification of volcanics in seismic data:

1. Basalts, even relatively thin layers, show typical geometries known from surface observations that can be identified on seismic data.

2. Basalts may display extremely high acoustic impedances and high vertical heterogeneity. They can be responsible for attenuation effects, which would be discovered by spectral decomposition/ spectral ratio analysis.

3. Volcanic layers and small edifices could be identified by differential compaction analysis, using curvature and high frequency structure images.

4. Volcaniclastics are multimineral, proximal, immature, poorly sorted sediments with a matrix-supported fabric. They exhibit significantly higher $\mathrm{Vp} / \mathrm{Vs}$ ratios than cleaner and better sorted grain-supported siliciclastics.

5. Due to the high $\mathrm{Vp} / \mathrm{Vs}$ ratio, basalts and volcaniclastics are likely to produce increasing AVO effects on hard kicks (high acoustic impedance layers) - porous sandstones usually show these effects on soft kicks.

6. The images and seismic response modeling of intrusive bodies, varying in dip and thickness, will help the seismic interpreter to identify them on his data set. In frontier areas, they could give indications as to whether we are dealing with volcanics.

\section{Acknowledgment}

The authors would like to thank all our colleagues (see references) for their friendly cooperation and fruitful discussions of the results.

\section{References}

Anjos, S. M. C., De Ros, L. F. \& Silva, C. M. A. (2003). Chlorite authigenesis and porosity preservation in the Upper Cretaceous marine sandstones of the Santos Basin, offshore eastern Brazil, In: Worden, R. H. \& Morad, S. (eds. ) Clay Cements in Sandstones: IAS Special Publication, International Association of Sedimentologists Blackwell Scientific Publications, Oxford, UK, 34, 291-316.

Avseth, P., Mukerij, T., Mavko, G. \& Tysskvam, J. A. (2001). Rock physics and AVO analysis for lithofacies and pore fluid prediction in a North Sea oil field. The Leading Edge, April 2001.

Avseth P., Mukerji T., \& Mavko G. (2005). Quantitative Seismic Interpretation: applying rock physics tools to reduce interpretation risk; Cambridge University Press.

Castagna, J. P. (1993). Amplitude-versus-offset analysis; tutorial and review. In: J. P. Castagna and M. M. Backus, Eds., Offset-Dependent Reflectivity - Theory and Practice of AVO Analysis, Society of Exploration Geophysicists.

De Ros, L. F., Mizusaki, A. M. P., Silva, C. M. A. \& Anjos, S. M. C. (2003). Volcanic rock fragments of Paraná Basin provenance in the Upper Cretaceous sandstones of 
Santos Basin, Eastern Brazilian Margin (abstract). $2^{\circ}$ Congresso Brasileiro de P\&G em Petróleo e Gás, Rio de Janeiro, Extended abstracts.

De Vincenzi, L. \& Klarner, S. (2002). Seismic reservoir characterisation of a fluvial reservoir, Nakhla oil field (Libya, onshore). EAGE 64th Conference \& Exhibition, Florence, Extended abstracts.

Dillon, L. D., Vasquez, G. F., Nunes, C. M., Neto, G. S., \& Velloso, R. Q. (2004). Atributos DHI (Indicadores Diretos de Hidrocarboneto) obtidos a partir do dado sísmicopréempilhamento: uma análise integrada da rocha à sísmica. Boletim de Geociencias da Petrobras, Rio de Janeiro, 12(1), 149-173.

Folk, R. L. (1968). Petrology of Sedimentary Rocks. Hemphill's, Austin, University of Texas Publication.

Gassmann, F. 1951. Über die Elastizität poroeser Medien, Vierteljahresschrift der Naturforschenden Gesellschaft in Zürich, 96, 1-23.

Garten, P., Houbiers, M., Planke, S., \& Svensen, H. (2008). Vent Complex at Heidrun. SEG Las Vegas 2008 Annual Meeting, Expanded abstracts.

Gidlow, P. M., Smith, G. C., \& Vail, P. J. (1992). Hydrocarbon detection using fluid factor traces: A case history, Extended abstracts of the Joint SEG/EAEG Summer Research Workshop on "How useful is Amplitude-Versus-Offset (AVO) Analysis?", 78-89.

Graversen, O. (2006). The Jurassic-Cretaceous North Sea Rift Dome and Associated Basin Evolution. Search and Discovery Article \#30040, Posted February 19, 2006.

Greenberg, M. L. \& Castagna, J. P. (1992). Shear-wave velocity estimation in porous rocks; theoretical formulation, preliminary verification and applications. Geophysical Prospecting, 40, 195-209.

Hanitzsch, C., deVincenzi, L., Heerde,W., Michel, J. M. \& Semond, D. (2007). Dual inversion applied to 2D multi-component seismic data onshore Libya; first break volume 25, April 2007, pp 49-54.

Klarner, S., Culpan, R. \& Smith, T. (2005). An enhanced AVO model for lithologically complex sandstones in the Santos Basin, Brazil. 75th Meeting, Society of Exploration Geophysicists, Houston, Expanded abstracts.

Klarner, S., Klarner, O. \& Ujetz, B. (2006). Rock properties of complex lithologies similarities between Offshore Brazil and West Siberia. EAGE Conference Saint Petersburg, Extended abstracts.

Klarner, S., Ujetz, B., Fontana, R. \& Altenkirch, J. (2006). Seismic Signature of Upper Cretaceous Volcanics; Santos Basin, Brazil. EAGE 68th Conference \& Exhibition, Vienna, Extended abstracts.

Klarner, S., Culpan, R., Fontana, R. \& Bankhead, B. (2006). Identification of Upper Cretaceous Volcanics using AVO Attributes; Santos Basin, Brazil. EAGE 68th Conference \& Exhibition, Vienna, Extended abstracts.

Klarner, S., Ujetz, B. \& Fontana, R. (2008). Enhanced depositional and AVO models for lithologically complex sandstones in the Santos Basin, offshore Brazil. Petroleum Geoscience, Vol. 14 /3. 2008, pp. 235-243.

Klarner, S. \& Zabrodotskaya, O. (2009): Rock physics in complex reservoirs - the key to understanding their seismic responses. EAGE/SEG Conference Tyumen, Extended abstracts. 
Klarner, S., Kruglyak, V. F. \& Lewis A. J. (2009): Anomalous elastic properties - an example from offshore Sakhalin. EAGE Conference and Exhibition Amsterdam, Extended abstracts.

Li, L., Wu, Q., Zhao, H. \& Wu, X. (2009). Laboratory analysis of seismic parameters of volcanic rock samples from Daqing Oilfield. SEG Houston 2009 International Exposition and Annual Meeting. Expanded abstracts.

Mello, M. R., Mohriak, W. U., Koutsoukos, E. A. M. \& Bacoccoli, G. (1994). Selected Petroleum Systems in Brazil: AAPG memoir, 60, 499-512.

Mohriak, W. U., Rosendahl, B. R., Turner, J. T. \& Valente, S. C. (2002). Crustal architecture of the South Atlantic volcanic margins. In: Menzies, M. A., Klemperer, S. L., Ebinger, C. J., \& Baker, J. (eds. ) Volcanic Rifted Margins. Geological Society of America Special Paper, Boulder, Colorado, 362, 159-202.

Mukerji,T., Gonzalez, E. , Cabos, C., Hung, E., Mavko, G. (2002). Understanding amplitude anomalies and pitfalls in offshore Venezuela; quantifying the effects of geologic heterogeneities using statistical rock physics. Society of Exploration Geophysicists, International exposition and 72nd annual meeting, Salt Lake City, UT, United States. Oct. 6-11, 2002; Technical program, Expanded abstracts with authors' biographies. 72; Pages 2439-2442.

Nelson, C. E., Jerram, D. A. \& Hobbs, R. W., (2009). Flood basalt facies from borehole data: implications for prospectivity and volcanology in volcanic rifted margins. Petroleum Geoscience, Vol. 15 2009, pp. 313-324.

O’Halloran, G. J. \& Johnstone, E. M. (2001). Late Cretaceous rift volcanics of the Gippsland Basin, SE Australia - new insights from 3D seismic. In: Hill, K. C. \& Bernecker, T. (eds) 2001. Eastern Australasian Basins Symposium, A Refocussed Energy Perspective for the Future, PESA, Special Publication, 353-361.

Ortin, A., Sanchez, E. \& Bustos, U. (2005). Reservoir characterization in volcaniclastics; EAGE 67th Conference \& Exhibition - Madrid, Spain, 13 - 16 June 2005, extended abstracts.

Ottesen, C., Heerde, W. \& Weihe, T. (2005). Tectono-Stratigraphic Evolution and Controls on Volcanics in Early Cretaceous in Hameimat Area, Libya EAGE 67th Conference \& Exhibition - Madrid, Spain, 13 - 16 June 2005. Extended abstracts.

Pena, V., Sarkar, S., Marfurt, K. J. \& Chávez-Pérez, S. (2009). Mapping Igneous Intrusive and Extrusive from 3D Seismic in Chicontepec Basin, Mexico. SEG Houston 2009 International Exposition and Annual Meeting, Expanded abstracts.

Peterson, D. W., \& Tilling, R. I., (1980). Transition of basaltic lava from pahoehoe to aa, Kilauea Volcano, Hawaii: field observations and key factors: Journal of Volcanology and Geothermal Research, v. 7, p. 271-293.

Planke, S., Alvestad, E., \& Eldholm, O. (1999). Seismic characteristics of basaltic extrusive and intrusive rock, The Leading Edge, March 1999, pp 342-348.

Polyaeva, E., Lowrey, C. J., Klarner, S. \& Zabrodotskaya, O. (2011). Depth dependent rock physics trends for Triassic reservoirs in the Norwegian Barents Sea EAGE 73th Conference \& Exhibition incorporating SPE EUROPEC - Vienna, 2005. Extended abstracts.

Porębski, S. J. \& Steel, R. J. (2003). Shelf-margin deltas: their stratigraphic significance and relation to deepwater sands. Earth-Science Reviews, 62, 283-326. 
Porębski, S. J. \& Steel, R. J. (2006). Deltas and Sea-Level Change. Journal of Sedimentary Research, 76 (3), 390-403.

Ross, C. P. 2002. Comparison of popular AVO attributes, AVO inversion, and calibrated AVO predictions. The Leading Edge, March 2002, 244-252.

Rutherford, S. R. \& Williams, R. H. (1989). Amplitude-versus-offset variations in gas sands. Geophysics, 54, 680-688.

Schminke, H. -U. (2000). Vulkanismus. Wissenschaftliche Buchgesellschaft Darmstadt.

Scotchman, I. C., Carr, A. D. \& Parnell, J. (2002). Hydrocarbon Generation Modelling along the UK North eastern Atlantic margin. AAPG Hedberg Conference, Hydrocarbon habitat of volcanic rifted passive margins, Stavanger, Abstracts.

Smith, T. M., Sondergeld, C. H. \& Rai, C. S. (2003). Gassmann fluid substitutions: a tutorial. Geophysics, 68, 430-440.

Thomson, K. \& Hutton, D. 2004. Geometry and growth of sill complexes: insights using 3D seismic from the North Rockall Trough. Bull Volcanol 66:364-375.

Thomson, K. (2005). Volcanic features of the North Rockall Trough: application of visualisation techniques on 3D seismic reflection data Bull Volcanol 67:116-128.

Vernik, L. (1994). Predicting lithology and transport properties from acoustic velocities based on petrophysical classification of siliciclastics. Geophysics, 53(3), 420-427.

Wu, C., Gu, L., Zhang, Z., Ren, Z., Chen, Z., \& Li, W. (2006). Formation mechanisms of hydrocarbon reservoirs associated with volcanic and subvolcanic intrusive rocks: Examples in Mesozoic-Cenozoic basins of eastern China. AAPG Bulletin, v. 90, no. 1 (January 2006), pp. 137-147.

Yang J., Mao, H., Chang, X., Zhu, M., Wang, X. \& Zou, Y. (2008). Mu-rho direct inversion for volcanic rock reservoir prediction: a case study of the Dinan Field, Junggar Basin. SEG Las Vegas Annual Meeting. Expanded abstracts.

Zhao G. L., \& Y. Q. Zhang, (2002). Seismic reflection character of volcanic reservoir of Daqing and the comprehensive prediction technology: Petroleum Exploration and Development, 29, 44-46. 


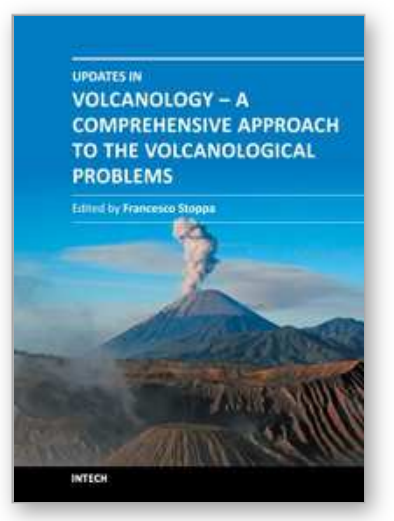

\section{Updates in Volcanology - A Comprehensive Approach to Volcanological Problems}

Edited by Prof. Francesco Stoppa

ISBN 978-953-307-434-4

Hard cover, 242 pages

Publisher InTech

Published online 13, January, 2012

Published in print edition January, 2012

This book ranges from the geologic-petrologic description of world-wide major volcanic fields unfamiliar to international literature, to the discussion and interpretation of the results in light of geophysical techniques. It focuses on several situations that represent large-scale volcanism on Earth, related both with intra-plate or active margins. Many large volcanic complexes of Easter countries are presented, including Japan, Siberian Russia, and Mongolia. A detailed account of the European volcanic province of the Pannonia basin and Central-Southern Spain is given. Southern hemisphere areas of Antarctica and Polynesia are considered as well. The chapters are very informative for those who wish for a guide to visiting, or are curious about main characteristics of the above volcanic areas, some of which are remote and not easily accessible.

\section{How to reference}

In order to correctly reference this scholarly work, feel free to copy and paste the following:

Sabine Klarner and Olaf Klarner (2012). Identification of Paleo-Volcanic Rocks on Seismic Data, Updates in Volcanology - A Comprehensive Approach to Volcanological Problems, Prof. Francesco Stoppa (Ed.), ISBN: 978-953-307-434-4, InTech, Available from: http://www.intechopen.com/books/updates-in-volcanology-acomprehensive-approach-to-volcanological-problems/identification-of-paleo-volcanic-rocks-on-seismic-data

\section{INTECH}

open science | open minds

\section{InTech Europe}

University Campus STeP Ri

Slavka Krautzeka 83/A

51000 Rijeka, Croatia

Phone: +385 (51) 770447

Fax: +385 (51) 686166

www.intechopen.com

\section{InTech China}

Unit 405, Office Block, Hotel Equatorial Shanghai

No.65, Yan An Road (West), Shanghai, 200040, China

中国上海市延安西路65号上海国际贵都大饭店办公楼 405 单元

Phone: +86-21-62489820

Fax: +86-21-62489821 
(C) 2012 The Author(s). Licensee IntechOpen. This is an open access article distributed under the terms of the Creative Commons Attribution 3.0 License, which permits unrestricted use, distribution, and reproduction in any medium, provided the original work is properly cited. 